\title{
La educación para el ocio como preparación para la jubilación en Estados Unidos y España
}

\author{
Leisure Education for retirement preparation in the United States and Spain
}

Educar livre para se preparar para a aposentadoria em os EUA e Espanha

\author{
Douglas A. Kleiber \\ UNIVERSITY OF GEORGIA \\ Fernando Bayón Martín y Jaime Cuenca Amigo \\ UNIVERSIDAD DE DEUSTO
}

\section{Resumen}

El envejecimiento de las poblaciones y la mayor esperanza de vida han atraído una creciente atención sobre los factores que afectan la calidad de vida en la tercera edad. La idea de que la educación se dirige sobre todo a los jóvenes es ya obsoleta y este artículo argumenta que una de las principales necesidades educativas en el curso vital viene suscitada por la transición a la jubilación. Específicamente, esta transición implica un radical desplazamiento en el peso relativo del trabajo y el ocio, dos conceptos que están sujetos a una comprensión e interpretación en ocasiones demasiado estrechas, especialmente en las culturas occidentales. Este artículo se propone como objetivos clarificar el significado y potencial del ocio en la adaptación a la jubilación; considerar los efectos de diferentes sistemas nacionales de jubilación, especialmente los de Estados Unidos y España, sobre la adaptación a la jubilación; identificar el estado actual de los programas de preparación para la jubilación en estos dos países; demostrar el valor de prestar una mayor atención al ocio en estos programas; $y$ ofrecer estrategias para llevarlo a cabo.

\section{Abstract}

Aging populations and extended lifespans have drawn increased attention to factors affecting the quality of later life. The assumption the education is primarily about youth has consistently been challenged and this paper argues that one of the greatest educational needs of the lifecourse is in managing the retirement transition. Specifically, this transition involves a dramatic shift of focus from work to leisure, but both of those concepts are subject to limited understanding and interpretation in western cultures especially. This article takes as its purpose the tasks of clarifying the meaning and potential of leisure in adjusting to retirement; elaborating the effects of different national retirement systems, specifically those of the United States and Spain, on adaptation to retirement; identifying the current status of retirement preparation programs in these two countries; demonstrating the value of giving greater attention to understanding leisure in these programs; and offering strategies for doing so.

LA EDUCACION PARA EL OCIO COMO PREPARACION PARA LA JUBILACION EN... [ 137 ] SIPS - PEDAGOGIA SOCIAL. REVISTA INTERUNIVERSITARIA [1139-1723 (2012) 20, 137-176] • TERCERA EPOCA 
PALABRAS CLAVE: jubilación, jubilación obligatoria, educación previa a la jubilación, ocio, educación del ocio, envejecimiento (individuos), etapas del desarrollo.

\section{Resumo}

Envelhecimento da população e expectativa de vida longos têm atraído maior atenção a fatores que afetam a qualidade de vida mais tarde. O pressuposto a educação é principalmente sobre a juventude tem sido constantemente desafiado e este artigo argumenta que uma das maiores necessidades educacionais da lifecourse está na gestão da transição de aposentadoria. Especificamente, esta transição envolve uma mudança radical de foco do trabalho ao lazer, mas ambos os conceitos estão sujeitos a limitada compreensão e interpretação nas culturas ocidentais, principalmente. Este artigo tem como objetivo as tarefas de esclarecer o significado eo potencial de lazer na adaptação para a reforma; elaborar os efeitos de diferentes sistemas de reforma nacionais, especificamente as dos Estados Unidos e Espanha, sobre a adaptação para a reforma, identificando o estado atual da aposentadoria programas de preparação nesses dois países, demonstrando o valor de dar maior atenção ao lazer compreensão nestes programas, e oferecer estratégias para fazê-lo.

PALAVRAS-CHAVE: aposentadoria, aposentadoria compulsória, a educação pré-aposentadoria, lazer, educação, lazer, envelhecimento (pessoas físicas), estágios de desenvolvimento.

\section{Introducción}

En la película A propósito de Schmidt, Warren Schmidt, interpretado por Jack Nicholson, mira el reloj cuando concluye lúgubremente su último día de trabajo. En los días siguientes, en los que también se produce la inoportuna muerte de su esposa, le vemos vagar sin rumbo de forma que resulta a veces divertida
KEY WORDS: retirement, compulsory retirement, preretirement education, leisure, leisure education, aging (individuals), developmental stages.

\section{Resumo}

Envelhecimento da população e expectativa de vida longos têm atraído maior atenção a fatores que afetam a qualidade de vida mais tarde. O pressuposto a educação é principalmente sobre a juventude tem sido constantemente desafiado e este artigo argumenta que uma das maiores necessidades educacionais da lifecourse está na gestão da transição de aposentadoria. Especificamente, esta transição envolve uma mudança radical de foco do trabalho ao lazer, mas ambos os conceitos estão sujeitos a limitada compreensão e interpretação nas culturas ocidentais, principalmente. Este artigo tem como objetivo as tarefas de esclarecer o significado eo potencial de lazer na adaptação para a reforma; elaborar os efeitos de diferentes sistemas de reforma nacionais, especificamente as dos Estados Unidos e Espanha, sobre a adaptação para a reforma, identificando o estado atual da aposentadoria programas de preparação nesses dois países, demonstrando o valor de dar maior atenção ao lazer compreensão nestes programas, e oferecer estratégias para fazê-lo.

PALAVRAS-CHAVE: aposentadoria, aposentadoria compulsória, a educação pré-aposentadoria, lazer, educação, lazer, envelhecimento (pessoas físicas), estágios de desenvolvimento.

\section{Introduction}

In the film, About Schmidt, Warren Schmidt, played by Jack Nicholson, watches the clock as his last day on the job comes to a grim conclusion. In the days that follow, which also include the untimely death of his wife, he is depicted wandering aimlessly in ways that are in turn amusing and unsettling but consis- 
y a veces inquietante, aunque siempre deprimente, en tanto que expresión de los años que le aguardan tras la jubilación. Da la sensación de que no estaba en absoluto preparado para este acontecimiento, a pesar de tener la economía en orden, haber saldado las deudas y tener una salud razonablemente buena. Está claro que no sabe qué hacer consigo mismo.

El tiempo libre es sin duda uno de los nuevos elementos de la ecuación para Warren Schmidt, aumentado aún más por la muerte de su esposa. Por mucho que pueda ser una bendición, un aumento repentino del tiempo libre es inevitablemente un problema, como le sucedió a Warren. La gestión del tiempo libre durante todo el curso vital es uno de los objetivos de la educación para el ocio. Sin embargo, el problema puede agudizarse sobre todo cuando uno se encuentra frente a un cambio significativo en la cantidad de tiempo disponible, como sucede cuando se deja de trabajar o las responsabilidades familiares se reducen de manera sustancial. Por esta razón, un poco de educación o de asesoramiento al respecto puede resultar necesario y beneficioso.

La educación para el ocio puede entenderse de diferentes maneras (cf. Albrechtsen, 2001; Kleiber, 2012). Puede ser la protagonista de las enseñanzas tal como la consideraremos aquí, pero también pueden ser los propios medios de educación. Está claro que la gente aprende mucho en el contexto del ocio, en la medida en que resulta adecuado a efectos educativos como sucede en el aprendizaje empírico, el aprendizaje al aire libre, el aprendizaje de actividades de riesgo, etc. De hecho, los argumentos a favor de las actividades extracurriculares y co-curriculares en las instituciones de enseñanza suelen estar respaldados por lo que los niños y otros aprenden "fuera de la clase". Gran parte de este razonamiento se basa en los supuestos y demostrados "beneficios" del ocio, sobre los que volveremos en breve, especialmente aquellos relacionados con la vida en la edad tardía. La educación para el ocio puede considerarse también aquello tently depressing as a rendering of post retirement years. There is a sense that he was totally unprepared for this event, despite having his finances in order, his accounts settled, and being in reasonably good health. He clearly doesn't know what to do with himself.

Free time is obviously one of the new elements in the equation for Warren Schmidt, increased even by the loss of his wife. As much as it may be a blessing, a sudden increase in free time is inevitably a problem as it clearly was in Warren's case. The management of free time is one of the objectives of leisure education, throughout the life course. The problem may be particularly acute, though, as one faces a significant change in the call on one's time as is the case with the end of full time work or a significant reduction in family responsibility. For this purpose some amount of education - or counseling may be needed and beneficial.

Leisure education can be understood in different ways (cf. Albrechtsen, 2001; Kleiber, 2012). It can be the subject of education as we will consider here, but it may also be the means of education. Clearly people learn a great deal in the context of leisure, so much so that it is often appropriated for educational purposes as in experiential education, outdoor education, adventure education etc. Indeed, arguments for extracurricular and co-curricular activities in public schools are often supported by what children and others learn "outside the classroom," Much of this reasoning is based on the presumed and demonstrated "benefits" of leisure, to which we also turn shortly, especially those related to later life. Leisure education might also be understood as what happens in university programs dealing with the management of leisure as well as tourism, sports and related activities. Such is the case for the authors in our two universities. But the focus of this article is on how leisure might be presented and constructed as a subject of consideration for those who are preparing for retirement, knowing that in 
que en los programas universitarios trata de la gestión del tiempo libre, así como los cursos relacionados con el turismo, los deportes y actividades afines. Tal es el caso de los autores de nuestras dos universidades. Pero en lo que se centra este artículo es en cómo puede presentarse e interpretarse el ocio como actividad para aquellos que se están preparando para la jubilación, teniendo en cuenta que, en el mejor de los casos, su comprensión del asunto suele ser ambigua y, en el peor, una fuente de consternación y malestar, o como en el caso de Warren Schmidt carecen totalmente de cualquier punto de vista.

\section{El tema de la educación para el ocio en la jubilación}

Al comenzar a analizar la idea de la educación para el ocio en la jubilación nos encontramos con dos problemas: comprender el impacto de la jubilación y entender más claramente el significado y el potencial del ocio. El ocio puede ser el más ambiguo de los términos que vamos a analizar, pero la idea de que pueda ser tema de enseñanza o utilizado para otros objetivos educativos plantea un desafío particular.

\subsection{La naturaleza de la jubilación}

Se ha escrito mucho sobre la jubilación, pero uno de los estudios más convincentes sobre el tema fue llevado a cabo en Estados Unidos por Robert Weiss (2005) mediante la realización de cuatro entrevistas antes y después de la jubilación a 89 hombres y mujeres de una amplia muestra de la sociedad de Massachusetts. Weiss escribió sobre sus experiencias antes, durante y después de la jubilación relacionadas con las razones que les llevaron a jubilarse, las circunstancias en las que dejaron el trabajo, qué ganaron y qué perdieron como resultado de ello, en qué medida figuraban en el proceso el dinero, la familia, la salud y las actividades, y cómo se habían adaptado a todo ello, concluyendo el estudio con algunas recomenda- some cases their understanding of leisure is ambiguous at best, a source of consternation and antipathy at worst, or perhaps lacking all together, as it seems to have been with Warren Schmidt.

\section{The case for leisure education at retirement}

As we begin to examine the idea of leisure education at retirement we are faced with two problems: understanding the impact of retirement and more clearly understanding the meaning and potential of leisure. Leisure may be the most ambiguous of the terms we will consider, but the ideas that it might be the subject of education or mobilized for other educational purposes creates a particular challenge.

\subsection{The nature of retirement}

Much has been written about retirement, but one of the more compelling studies of retirement in the United States was done by Robert Weiss (2005) in conducting four interviews before and after retirement with each of 89 men and women from a good cross section of eastern Massachusetts society. Weiss wrote about their experiences before, during and after retirement with respect to the reasons for their retirement, the circumstances of their departure from work, what was gained and lost as a result, how money, family, health and activities figured into the process, and to their adjustment to it all, and he ended with recommendations. 
ciones. Consideraremos sus recomendaciones cuando expongamos las nuestras, pero su tratamiento de las pérdidas y ganancias nos da un buen punto de partida para establecer la necesidad de prepararse para la jubilación y educarse para el tiempo libre. También suscita las cuestiones de las diferencias en casos como el de España en que existe una edad de jubilación preestablecida.

\section{2. ¿Qué se pierde al jubilarse?}

Weiss (2005), y otros antes que él (Adams \& Beehr, 2003; Atchley, 1989) han reconocido que por muy pesado que sea el trabajo, tiene importantes características que a menudo son difíciles de reemplazar cuando se abandona. Entre otras podemos citar la estructura, las alegrías del compromiso, el sentido de utilidad y propósito, la identificación con un rol laboral particular y las relaciones sociales que rodean a la actividad profesional. Está claro que estas características pueden estar más o menos presentes en el trabajo de cada persona, pero cuanto mayor sea su proporción, más fuerte será la sensación de pérdida y mayor la dificultad para compensarla. La estructura de la jornada laboral aporta regularidad a la existencia para que ésta resulte previsible y estable. Pocas actividades de voluntariado ofrecen lo mismo que las 40, o más, horas semanales de la actividad laboral. En lo que respecta a disfrutar del compromiso con una tarea, puede que sea raro el trabajo que lo permita de una manera continuada, pero para muchos, este aspecto del trabajo, que se deriva de una profunda motivación, puede ser tan importante como el dinero que proporciona. De hecho, aunque las actividades de ocio pueden ofrecer intensas experiencias de disfrute, las pruebas nos hacen pensar que las actividades altamente absorbentes (las que nos hacen sentir que fluimos con ellas) son más abundantes en el trabajo que en el ocio (Csikszentmihalyi, 1990; Csikszentmihalyi \& LeFevre, 1989).
We'll consider his recommendations again along with our own, but his treatment of gains and losses gives us a good starting point for establishing the need for retirement preparation and leisure education in particular. They also raise the questions for us of differences in cases such as Spain where there is a more fixed retirement age.

\subsection{What is lost in retiring?}

Weiss (2005), and others before him (Adams y Beehr, 2003; Atchley, 1989) have recognized that as onerous as work may be, it does have important characteristics that are often difficult to replace when it stops. These include structure, the joys of engagement, the sense of usefulness and purpose, identification with the particular work role, and the social relationships around the work activity. Of course, these characteristics may be more or less present in work for a given individual, but the more strongly they are represented there the more extreme is the sense of loss and the greater the difficulty in compensating for that loss. The structure of the work day gives some regularity to existence that is predictable and stabilizing. With 40 or more hours per week regularly accounted for there are relatively few voluntary activities that offer the same. With respect to joyful engagement, it may be the rare job that is consistently engaging in an enjoyable way, but for many this part of work, the intrinsically motivated part, may be as important as the income derived. Indeed, while leisure activities do offer many ways to create intense enjoyable experience, the evidence suggests that highly absorbing ("flow"-like) experiences are still more common in work than in leisure (Csikszentmihalyi, 1990; Csikszentmihalyi y LeFevre, 1989).

That kind of high-involvement enjoyment is typically associated with compe- 
Ese tipo de disfrute que nos exige una elevada implicación suele estar asociado a la competencia, que es también una de las experiencias del trabajo difíciles de reemplazar cuando éste se acaba. De hecho, como veremos enseguida, es tal vez la experiencia más buscada en las actividades de ocio. Sin embargo, igual de importante es el sentido de utilidad y propósito que proporciona el trabajo y esto es incluso más difícil de reemplazar. La facilidad con la que las personas son sustituidas cuando se retiran puede tener que ver con su valor e importancia para la organización, pero la sensación interna de haber sido un miembro importante en un grupo o haber conseguido logros singulares pueden ser especialmente echados de menos con la jubilación. Para muchas personas, el trabajo es una importante fuente de identidad. Si uno es lo que hace, entonces, lo que has hecho durante años es lo que inevitablemente te define como persona, aunque para algunos supone más que para otros. Los roles profesionales, en especial, se convierten en intereses centrales de la vida y son definitorios de la personalidad, hasta el punto de que hay gente -médicos, abogados y profesores en el estudio de Weiss, por ejemplo-que siguen manteniendo esas identidades después de la jubilación, aunque la expresión relacionada con esos roles pueda estar limitada o incluso totalmente ausente. Este puede ser el reto más importante para la actividad pos-jubilación: encontrar otro sentido a la vida o reconstruirlo de forma adecuada. Por último, la reducción de las relaciones personales y sociales que acompañan al trabajo y lo rodean, hasta el punto de que lo trasciende como sucede en las asociaciones profesionales, representa una importante pérdida para muchos jubilados. A menudo se producen relaciones difíciles y antagónicas en torno al trabajo; pero también son comunes las alianzas y las auténticas amistades, y los trabajadores pueden llegar a depender en cierta medida de estas cosas. Los jubilados de Weiss mantuvieron algunas relaciones con los compa- tence, which is also one of the experiences of work that may be hard to replace when it is relinquished. In fact, though, it is perhaps the most sought-after experience in leisure activities as well shall see shortly. At least as important, however, is the sense of usefulness and purpose that work brings and this is even harder to replace. How easily people are replaced when they retire may bear on their sense of value and importance to the organization, but the internal sense of having been a contributing member of a group or having had singular accomplishments may be particularly missed upon retirement. For many, the work role is a significant source of identity; if you are what you do, then what you have done for years is inevitably personally defining, though for some more than others. Professional work roles especially become central life interests and are selfdefining to the point that people -the doctors, lawyers and professors in Weiss's study, for example- still hold onto those identities beyond retirement even though the related expression of those roles may be limited or absent all together. This may be the biggest challenge for post-retirement activity: replacing the sense of meaning or finding a suitable reconstruction of it. Finally, the diminishment of personal and social relationships in the workplace or even extending around the work role, to the extent that it transcends the workplace as it does in professional associations, represents a significant loss for most retirees. There often are difficult and antagonistic relationships in and around work, but alliances and true friendships are common in the workplace, and workers may come to be dependent to some extent on those things. Weiss' retirees maintained some relationships with fellow workers after retirement, at least for a while, and especially with those who also retired, but the lack of a direct connection to the job typically 
ñeros de trabajo después de la jubilación, al menos durante un tiempo, y especialmente con aquellos que también se habían jubilado, pero la falta de relación directa con el trabajo suele desestabilizar dichas relaciones dado que estaban íntimamente conectadas con el mismo. En cualquier caso, incluso las relaciones surgidas del ocio se forman, en buena medida, con aquellos que son compañeros de trabajo en primer lugar. A pesar de todos sus obstáculos, los entornos laborales crean un sentido de camaradería e incluso de comunidad. Esto es especialmente difícil de reemplazar en la jubilación.

Al pensar sobre estos aspectos en aquellos entornos donde la jubilación es obligatoria, tal vez resultan aún más significativos allí donde la decisión de jubilarse escapa al control de uno mismo. Cuando la jubilación es forzosa en EE.UU., los trabajadores sienten una pérdida de control que tiene implicaciones en la satisfacción vital durante la jubilación (Reitzes \& Mutran, 2004). Y aunque el aplazamiento de la posibilidad de optar a prestaciones sociales incrementa las probabilidades de llegar a la jubilación con mala salud, lo cual tiene el efecto de minar la adaptación pos-jubilación (Calasanti, 1996), cuando se abolió la jubilación obligatoria en EE.UU. en la década de 1960, se consideró que el control sobre el calendario de jubilación proporcionaba una mayor satisfacción vital.

Por otro lado, tal vez la mera aceptación de estas pérdidas como algo inevitable, hace que sean más fácilmente gestionadas cuando se sabe que hay una edad obligatoria. En el caso de países como España, con una edad de jubilación fijada en los 65 años (tras la reforma, se prevé aumentarla gradualmente hasta llegar a los 67 años como edad obligatoria en 2027), es menos probable que ésta se atribuya a la incapacidad personal o la incompetencia profesional $y$, por lo tanto, que se viva como un "castigo". En cambio, la jubilación suele ser vista y aceptada como una convención social que reconoce igualdad de derechos para todos destabilizes such relationships to the extent they have been work-related. However, even leisure-based relationships are formed in large part with those who are Coworkers first. For all of its shortcomings, work environments do build a sense of camaraderie and even a sense of community. This is especially difficult to replace in retirement.

In thinking about all those things in forced retirement settings, perhaps they are even more significant if the decision to retire is out of one's hands. Where retirement is coerced in the U.S., workers feel a loss of control that has implications for life satisfaction into and through retirement (Reitzes y Mutran, 2004). And while the postponement of benefit eligibility increases the chances that retirement is entered into in poor health, which has the effect of undermining post retirement adaptation (Calasanti, 1996), when mandatory retirement was abolished in the US in the 1960s, higher life satisfaction was attributed to control over the timing of the retirement.

On the other hand, perhaps the mere acceptance of these losses as inevitable makes them more easily managed where a mandatory age can be anticipated. And in the case of countries like Spain, with a mandatory requirement at 65 , retirement is less likely to be attributed to personal incapacity or professional incompetence and treated as a kind of "punishment" for such. It's commonly seen and accepted rather as a social convention that recognizes an equal right for all workers (IMSERSO, 1999). This is, perhaps, the most influential factor in allowing senior citizens to better manage the losses derived from retirement. (It is also interesting to note that at the Spanish word for retirement -"jubilación”- comes from the Latin verb "iubilare" meaning shouts of joy - "iubili"- after being liberated from torture 
los trabajadores (IMSERSO, 1999). Éste es tal vez el factor más importante al permitir a los ciudadanos de más edad gestionar mejor las pérdidas derivadas de la jubilación. (Es acaso interesante observar, en este contexto, que la palabra española "jubilación" proviene del verbo latino "iubilare" que significa gritar de alegría - "iubili"- después de quedar liberado de la tortura del trabajo - "tripalium).

Dado el continuo aumento de la esperanza de vida en los últimos 100 años, está surgiendo un consenso en todo el mundo para que la edad obligatoria de jubilación sea retrasada (de hecho, Italia acaba de adoptar los 67 como la edad de jubilación obligatoria y España lo hará, como acabamos de referir, en 2027) o para que se elimine por completo la edad de jubilación obligatoria. Pero aunque estas políticas tienen en su mayoría motivaciones económicas, también reflejan una ideología subyacente acerca de la falta de dignidad y valía humana asociadas a la propia jubilación. Sin embargo, existen corrientes contrarias tanto en EE.UU. como en España que ven la jubilación como una época de compromiso activo y realización humana y por ello merecedora de una atención y preparación especiales independientemente de las circunstancias particulares que la provoquen.

En cualquier caso, es importante reiterar que en España, aunque no en todos los países en los que existe una edad de jubilación obligatoria, la jubilación no es vista, en términos generales, como un fallo personal o una disminución de facultades. No obstante, ello no significa necesariamente que las personas mayores aquí estén mejor preparadas para la jubilación que los trabajadores de países como EE.UU., donde no existe una edad de jubilación obligatoria. Al contrario, hemos encontrado dos factores adicionales que pueden explicar esta cierta falta de motivación y entusiasmo que tiene la gente para prepararse para la jubilación.

En primer lugar, aunque existe una edad establecida para la jubilación obligatoria a los -"tripalium"- which is also related to the English word, jubilation).

Because of steadily rising life expectancies over the last 100 years, there is emerging a worldwide consensus that the mandatory retirement age should either be pushed back to a higher age (indeed, Italy had just adopted 67 as the age of mandatory retirement and Spain will follow in 2027) or to eliminate mandatory retirement ages altogether. But while these policies are economically-driven to a great extent, they also reflect an underlying ideology about the lack of dignity and human worth associated with retirement itself. Nevertheless, there are countercurrents in the US and Spain both that see retirement as a time of active engagement and human fulfillment and thereby worthy of special attention and preparation regardless of the particular circumstances that create it.

In any case, it is important to reiterate that in Spain, if not all countries with a mandatory retirement age, retirement is not seen as implying to any personal fault or diminution of faculties. Nevertheless, this does not necessary mean that senior people here are better prepared for retirement than workers of countries, like USA, where mandatory retirement ages do not apply. On the contrary we have found two additional factors that can explain this certain lack of motivation and enthusiasm people have in preparing themselves for retirement:

First, although there is a mandatory requirement at 65 , early retirements before that age have been as popular in the Spanish labor market as they have been in the US and elsewhere. When working people take advantage of such options, they frequently lack much time for adequate preparation, and make the assumption that they will do whatever planning is necessary after their actual retirement. Fur-

[ 144 ] Douglas A. Kleiber, Fernando Bayón Martín y Jaime Cuenca Amigo

SIPS - PEDAGOGIA SOCIAL. REVISTA INTERUNIVERSITARIA [1139-1723 (2012) 20, 137-176] • TERCERA EPOCA 
65 años, las prejubilaciones antes de esa edad han sido en el pasado reciente tan populares en el mercado laboral español como lo han sido en Norteamérica y en otros lugares. Cuando los trabajadores se aprovechan de esas opciones, no suelen disponer de mucho tiempo para prepararse adecuadamente y dan por supuesto que ya harán planes después de la jubilación. Además, su cambio de estatus laboral suele ser complicado, absorbente y temporal, haciendo que toda planificación resulte difícil. Esto ocurre tanto con la jubilación parcial como con los contratos de sustitución o "relevo". Aunque el primer caso es la transición gradual del trabajo a la jubilación mediante la reducción de la jornada laboral y el acceso simultáneo a la jubilación parcial, el contrato de relevo se utiliza para cubrir el tiempo dejado libre por la jubilación parcial. A veces, se puede uno acoger a la jubilación anticipada en España gracias a este tipo de acuerdos de contrato relevo. A veces, se trata sólo de un efecto de un plan de "ajuste de plantilla" que reduce el personal. En ambos casos, los trabajadores mayores tienen una creciente sensación de inseguridad laboral que les dificulta planificar cuidadosamente su vida. En otras palabras, a medida que la gente se hace mayor sus expectativas de cuándo podrán retirarse cambian muy deprisa, produciendo un estado de considerable incertidumbre (MTAS, 1999).

Segundo: la edad de jubilación obligatoria establecida por el gobierno español tendrá que ser pronto retrasada a los 67 años por razones económicas y demográficas. Si en nombre de la sostenibilidad económica, la edad "normal" de jubilación es retrasada finalmente a los 67 años, en España y en otros países occidentales, es probable que se produzca una falta de motivación para participar en programas de "preparación para la jubilación” al menos inicialmente. Estos son los principales aspectos que sugieren unas pautas en España que comparten puntos comunes y diferencias con las de EE.UU. thermore, their change in employment status is often complicated, consuding and temporary, making planning very difficult. This occurs for both partial retirement and replacement or "relief" contracts. While the first is the gradual transition from work to retirement through reduced hours and simultaneous access to partial retirement, the relief contract is used to cover the time vacated by the partial retirement. Sometimes, early retirement can be made in Spain thanks to this kind of relief contract agreements. Sometimes, it is just an effect of a "labor force adjustment" plan that downsizes the staff. In both cases, senior workers have an increasing sense of employment insecurity that makes it hard to foresee carefully their life plans. In other words, as people get older their expectations of when they will be able to retire can change very fast, producing here a state of considerable uncertainty (MTAS, 1999).

Second: the mandatory retirement age enforced by the Spanish government has soon to be moved to 67 for demographic and economic reasons. If in the name of economic sustainability, the "normal" retirement age is eventually moving up to 67 , in Spain as in other western countries, a lack of motivation to get involved in "preparation for retirement" programs is likely to follow, at least initially. These are the main things that suggest patterns in Spain that are both similar to and different from those in the US. 


\section{3. ¿Qué se gana con la jubilación?}

Los participantes en el estudio de Weiss presentaban diversos grados de entusiasmo por la jubilación, aunque una de las razones más importantes que aducían para jubilarse era la posibilidad de tener más tiempo libre: "aproximadamente $1 / 5$ de nuestra muestra deseaba jubilarse no tanto por dejar los trabajos sino por disponer de más tiempo para el ocio" (Weiss, 2005: 20). En este caso, Weiss entiende por ocio "libertad" más que "actividad", aunque no esté claro que los participantes hicieran la misma distinción. Algunos pueden haber estado pensando en actividades específicas al decirlo, mientras que otros pueden haber destacado sólo la libertad y el abanico de posibilidades que ésta ofrece. "Libertad para pasar más tiempo con el cónyuge y la familia" formaba parte también de la motivación de muchos de los participantes en el estudio de Weiss. En general, las ganancias superaban a las pérdidas en los estudios de Weiss, especialmente la "libertad de iniciar nuevas actividades, vivencias y experiencias" (Weiss, 2005: 75), y la posibilidad de imponer el propio ritmo a la vida. "Desde la adolescencia no se había tenido una oportunidad semejante de organizar el tiempo de uno, libre de obligaciones y responsabilidades" (Weiss, 2005: 75).

La libertad también es concebida como capacidad para liberarse "de" - de los problemas del trabajo, sus presiones, exigencias, del tedio de las tareas repetitivas (más en los obreros), de los conflictos interpersonales (a todos los niveles) y de la constricción y carga de las limitaciones de tiempo (es decir, las pegas de la estructura). Los casos presentados por Weiss (2005) confirman que este efecto de "liberación" era más fuerte en unas personas que en otras, pero incluso aquellas que ocupaban cargos profesionales y ejecutivos esperaban la jubilación por esta razón y la valoraban precisamente por ello. Otros estudios sobre la jubilación lo confirman tanto como una expectativa positiva de la jubilación y

\subsection{What is gained in retirement?}

The participants in Weiss's study varied in their enthusiasm for retirement, but among their strongest reasons for retirement was the opportunity for more leisure: "about 1/5 of our sample wanted to retire not so much to leave their jobs as to gain retirement's leisure" (Weiss: 2005, 20). By leisure in this case, Weiss means freedom more than activity, though it isn't clear that participants made a similar distinction. Some may have been thinking about specific activities in saying that, while others may have relished the freedom alone and the range of possibilities it afforded. Freedom to spend more time with spouse and family was also part of the motivation of many of Weiss's participants. Generally, the gains outweighed the losses in Weiss's studies, especially the "freedom to engage in new activities, thoughts and experiences" (Weiss: 2005,75 ), and at a pace that is selfdetermined. "Not since adolescence has there been such opportunity to organize one's time free of obligations and responsibilities" (Weiss: 2005, 75).

The freedom is also reflected in freedom "from" - from the hassles associated with work, its pressures, demands, tedium of repetitive work (particularly in more blue collar workers), interpersonal conflicts (at all levels) and regimentation and burden of the time demands (i.e. the downside of structure). Weiss's (2005) cases confirm that this "relief" effect was stronger with some than others, but even those in professional and managerial positions looked forward to retirement for this reason and valued it in getting there. Other research on retirement confirms this as both a consistent positive expectation of retirement and a recognizable outcome (Gee y Baillie, 1999; Kim y Moen, 2002). It also addresses a concern about waning competence in the job role, where

[ 146 ] Douglas A. Kleiber, Fernando Bayón Martín y Jaime Cuenca Amigo

SIPS - PEDAGOGIA SOCIAL. REVISTA INTERUNIVERSITARIA [1139-1723 (2012) 20, 137-176] • TERCERA EPOCA 
como un resultado reconocible (Gee \& Baillie, 1999; Kim \& Moen, 2002). También aborda el problema sobre la merma de competencias en el desempeño del trabajo, cuando la edad y la disminución de la energía pueden tener como resultado una pérdida de capacidad o cuando un cambio de expectativas con respecto a la preparación tecnológica, por ejemplo, hace que el trabajador se sienta amenazado y con sentimientos de obsolescencia y pérdida de valor para la organización. Una vez más, ello puede ser quizás menos problemático en España donde la edad de jubilación obligatoria tiende a delimitar dicha auto-evaluación.

$\mathrm{Al}$ combinarse con las nuevas libertades que se adquieren, la liberación de las exigencias del trabajo hace que la jubilación sea una transición menos traumática en última instancia de lo que algunos hubieran imaginado, incluso para los que la están experimentando. Evidentemente ello no quiere decir que la transición sea sencilla o no resulte problemática para muchos (cf. Hayslip, Beyerlein, \& Nichols, 1997; Szinovicz, 2002). Depende a menudo de las propias circunstancias de la jubilación, especialmente de tener los recursos necesarios para disfrutar de las nuevas libertades y de tener control sobre el proceso. Weiss buscó una muestra amplia de la sociedad, pero parece que se centró algo más en aquellas personas que disponían de los recursos adecuados, aunque fueran de la clase trabajadora. Y aunque tuvo en cuenta las condiciones del lugar de trabajo que "empujaban" a la gente hacia la jubilación, el contexto estaba formado por gente que tenía por lo general cierto control sobre cómo y cuándo se retiraban de la vida laboral.

Las tensiones provocadas por tener que decidir cuándo retirarse, que existen en países como EE.UU., pueden no producirse en aquellos países donde la jubilación es obligatoria a los 65 o más tarde, como sucede en España. Los jubilados en España y en otros países donde existe una edad obligatoria para la ju- age and lower energy may have resulted in some loss of capacity or where changed expectations with respect to technological competence, for example, leaves a worker threatened with feelings of obsolescence and loss of value to the organization. Again, this may be less problematic in Spain where a mandatory retirement age tends to delimit such selfassessment.

In combination with the new freedoms afforded, the freedom from the demands of work makes retirement a less ultimately traumatic transition than some have imagined it would be, even those going through it. Of course, this in not to say that the transition is easy or that it isn't troublesome for many (cf. Hayslip, Beyerlein, yNichols, 1997; Szinovacz, 2002). And it does depend often on the circumstances of retirement, especially having necessary resources to enjoy new freedoms and also control over the process. Weiss sought a cross section of society in his study, but seemed to focus somewhat more on those with adequate resources, even among working class participants. And while he considered conditions in the workplace that "pushed" people into retirement, the context was that people usually had some control of how and when they retired.

The stresses of having to decide when to retire that apply in countries like the US may not apply in those countries with mandatory requirement, whether at 65 or later, as is the case in Spain. Retirees in Spain and other countries with mandatory retirement ages are saved the agonies that sometimes come with the deliberations about when and how to retire. On the other hand that also takes the control of the matter out of the hands of the individual to some extent and may lead to retirements that are arguably "too early" psychologically and socially or "too late". In the first case, the externality of the decision may prevent 
bilación no tienen que sufrir las agonías que a veces acompañan a las decisiones de cuándo y cómo jubilarse. Por otro lado, ello también arrebata, en cierto modo, el control del asunto de las manos de la persona implicada y puede provocar que existan jubilaciones que se produzcan psicológica y socialmente "demasiado pronto" o "demasiado tarde". En el primer caso, el que la decisión sea ajena a la persona, puede impedir que ésta haga el "trabajo" de jubilarse psicológicamente. Y él o ella pueden llegar a los 65 años sin haberse preparado para pasar de la vida laboral a otro tipo de vida. Las limitaciones para trabajar después de la jubilación también reducen las opciones de una jubilación escalonada o "trabajos puente" que son muy comunes en EE.UU., es decir, que procuran la posibilidad de que la transición resulte más paulatina. Si asociamos la brusquedad de la transición a más dificultades que cuando se realiza una transición planificada y escalonada como ocurre en EE.UU., podríamos esperar que hubiera más problemas de adaptación en países donde las leyes imponen una edad de jubilación fija.

Sin embargo, este no parece ser necesariamente el caso de España. En primer lugar, hay que tener en cuenta la tradicionalmente fuerte identificación de la ciudadanía española con el concepto europeo del estado de bienestar (Sáez Carreras y García Molina, 2003: 196), concepto de gobierno en el que el Estado desempeña un papel clave en la protección de la gratuidad y universalidad de la asistencia educativa y sanitaria (entre otros servicios públicos capitales, como la cobertura por desempleo). Podemos llegar a suponer que se demuestra lo contrario; es decir, que, hasta la llegada de la crisis, en una gran medida los ciudadanos españoles se sienten más cubiertos por el ámbito público (Pérez, 2002; Szinovacs, 2002). Desde este punto de vista, ninguna jubilación anticipada es "demasiado anticipada" cuando la gente se siente protegida por el estado de bienestar. De hecho, está claro que existe una auténtica resistencia popular a re- a person from doing the "work" of retiring psychologically. And he or she may reach 65 unprepared to step away from work into a different kind of life. Restrictions on working after retirement also limit the options of phased retirement or "bridge jobs" that are common in the U.S., i.e. the ability to make a more gradual transition. If the suddenness of the transition is associated with more difficulty than a phased and planned retirement transition as in the US, then one might expect more adjustment problems in countries with mandatory retirement laws.

However, such does not appear to be the case for Spain. For one thing, one must consider the traditionally strong have to take identification of the Spanish citizenship with the European concept of the welfare state (Sáez Carreras; García Molina: 2003, 196), a concept of government in which the state plays a key role in protecting the gratuity and universality of sanitary assistance (among other public services). We can assume until proved otherwise that, to a large extend, the Spanish citizens feel themselves more covered by the public sphere (Pérez, 2002; Szinovacz, 2002). Under this point of view, no early retirement is "too early" when people feel themselves protected by the welfare state. In fact, it is clear that there is real resistance to moving the full retirement age up from 65 to 67 -which is supposed to be planned in order to guarantee social security.

Even with Weiss's longitudinal study, his after-retirement examination did not extend very far beyond what some have considered a "honeymoon period" (cf. Kim y Moen, 2002). Long term adjustment to retirement requires that the freedoms from and the freedoms to are actualized in satisfying lifestyle changes. Our contention based on other evidence is that this continued adjustment depends to a great extent on a reconstruction of leisure in ways 
trasar la edad de jubilación de los 65 a los 67 años -que se supone que se está planificando a fin de garantizar la seguridad social y la equidad intergeneracional. Incluso en el estudio longitudinal de Weiss, su análisis pos-jubilación no iba mucho más allá de lo que algunos han considerado un "periodo de luna de miel" (cf. Kim \& Moen, 2002). La adaptación a largo plazo de la jubilación exige actualizar la "liberación de" y la "libertad para", a fin de conseguir cambios satisfactorios en el estilo de vida. Nuestro argumento basado en otras pruebas sostiene que esta adaptación continua depende en gran medida de una reconstrucción del tiempo libre que compense y sustituya aquello que más se valoraba del trabajo y que permita encontrar significado y valor en un mundo que ya no está dominado por el trabajo.

\subsection{Aclarar el significado y el potencial del ocio}

El concepto de ocio tiene importancia histórica, y su origen se remonta a la polis en la antigua Grecia, un lugar donde la libertad se idealizaba como la oportunidad para la auto-expresión, el perfeccionamiento del carácter y una provechosa interacción social (de Grazia, 1962; Hemingway, 1988). Pero a lo largo del tiempo ha recibido otras interpretaciones en las diferentes culturas. En gran medida, especialmente en las culturas occidentales, el ocio se ha relacionado con el no trabajo, o tiempo libre, y por lo tanto, para algunos, la jubilación significa la transición a una vida de ocio. De manera más común, no obstante, consiste en una serie de actividades intrínsecamente motivadas, como practicar juegos, entretenimiento y turismo, así como artes y manualidades que están asociadas con el término. Esta interpretación del ocio, como una serie particular de actividades, tiene el efecto de asociarlo sólo con el placer y los caprichos, la gratificación que puede haber sido aplazada en cierta medida al tener que vérselas con el mundo del trabajo y la familia. En las culturas occidentales existe incluso una that compensate for and replace some of what was most valued about work but also finds meaning and value in a world that is not dominated by work.

2.4. Clarifying the meaning and potential of leisure

The concept of leisure has historical significance, with roots in the polis of Ancient Greece, a place where freedom was idealized as the opportunity for self-expression, refinement of character and thoughtful social intercourse (deGrazia, 1962; Hemingway, 1988). But it has also been socially constructed over time to mean others things and quite different things in different cultures. To a great extent, especially in Western cultures, leisure has come to be equated with non-work, or free time, and thus for some, retirement suggests a transition to a life of leisure. More commonly, though, it is a set of intrinsically-motivated activities, such as play and games, entertainment and tourism, and arts and crafts that are associated with the term. This construction of leisure, as a particular set of activities, has the effect also of associating it only with pleasure and self-indulgence, the gratification that might have been delayed to some extent in contending with the world of work and family. There is even a sense of entitlement to this set of ex- 
sensación de tener derecho a este tipo de experiencias por haber sido "ganadas" a través de años de trabajo y compromisos familiares y donde se puede disponer de la ayuda financiera del gobierno y de los ahorros personales. Pero hay otras formas de pensar el ocio para estos tiempos y para otros, más próximas a sus ideales históricos y también a su potencial para disfrutar de un envejecimiento satisfactorio.

De acuerdo con los antiguos valores del ocio en la cultura occidental, los estudiosos del tema también han reconocido que las experiencias que se buscan en el ocio incluyen más cosas que aquellas que proporcionan una gratificación inmediata. De hecho, dada la libertad asociada al ocio, existen tantas razones para relacionarlo con la auto-realización que con el trabajo y, en ese contexto, constituye ese campo de auto-análisis y crecimiento que tan importante era para los griegos. Además, la idea del disfrute, aunque se asocia adecuadamente con actividades intrínsecamente motivadas, también incluye la existencia de un reto, y en algunos contextos, en el ocio se acometen retos que el placer solo no procura. Para la gente no es un oxímoron "trabajar" en actividades de ocio y tomárselas seriamente (Stebbins, 1992; 2001). Puede haber tanto esfuerzo y perseverancia en las actividades de ocio como no los hubo jamás en el trabajo; y en muchas actividades, como por ejemplo la jardinería, el proceso puede ser tan importante como los resultados. Por último, la posibilidad de que el ocio pueda ser utilizado en el discurso social durante la creación de comunidades lo acerca aún más a sus significados clásicos (Hemingway, 1988; Cuenca Cabeza, 2000; Maynard \& Kleiber, 2005). Pero en el tema del ocio, aunque los fines también importen, siguen siendo los medios lo más importante en casi todas sus conceptualizaciones.

Lo que más obstaculiza el poder tener una visión adecuada del ocio en la vejez es la opinión imperante de que es, en el mejor de los periences in western cultures where it has been "earned" through years of work and/or family-building and where financial support from government sources and personal savings are available. But there are other ways to think of leisure for this time, and for others, that come closer to representing its historical ideals and also its potential for contributing to successful aging.

Somewhat more in keeping with the ancient values of leisure in western culture, leisure scholars have also recognized the experiences sought in and as leisure as more inclusive than those implied only in immediate gratification. Indeed, given the freedom associated with it, there is as at least as much reason to associate self-expression with leisure as with work and it thus becomes the context for self-exploration and growth in much the way it did for the Greeks. Furthermore the idea of enjoyment, while appropriately associated with intrinsically motivated activities does not preclude the value of challenge and in some conceptualizations depends on challenge in ways that pleasure alone does not. It is not an oxymoron for people to "work" at leisure activities and to take them seriously (Stebbins, 1992, 2001). There may be as much effort and perseverance in leisure activities as there ever was in work; and for many activities such as gardening, exercising, and volunteer work, the outcomes may be as important as the process. Finally, the prospect that leisure can be used in social discourse in community building ways also brings it closer to its classical meanings (Hemingway, 1988; Cuenca Cabeza, 2000; Maynard y Kleiber, 2005). But with leisure in any case, the means -how one feels- is still the important thing in nearly all conceptualizations, even if the ends also matter.

What most obstructs an effective appropriation of leisure in later life is the prevailing view that it is, at best, the self-grat-

[ 150 ] • Douglas A. Kleiber, Fernando Bayón Martín y Jaime Cuenca Amigo

SIPS - PEDAGOGIA SOCIAL. REVISTA INTERUNIVERSITARIA [1139-1723 (2012) 20, 137-176] • TERCERA EPOCA 
casos, la auto-gratificación de descanso y placer ganados solamente con/tras el trabajo. Se trata de un vestigio de la herencia judeo-cristiana y la ética del trabajo protestante que han influido incluso en los países predominantemente católicos del hemisferio occidental desde la Revolución Industrial. Sin trabajo, e incluso después de éste, el ocio es sospechoso, considerado algo trivial y sin importancia por derecho propio, una actividad frívola e improductiva allí donde la productividad sigue siendo el estándar del valor. Si se teme la jubilación y se accede a ella con un sentimiento de falta de valor, de que lo respetable es la actividad laboral, en ese caso el ocio evidentemente no es la respuesta. Para muchos, la educación para el ocio requeriría deshacerse de esa idea, de que el valor sólo reside en la productividad y que la tranquilidad y gratificación no ganadas carecen de valor. Otros deberían llegar a aprender que el tiempo libre puede ser utilizado de muchas maneras "productivas", en trabajo a tiempo parcial o de voluntariado, haciendo cosas para los demás y encontrando en el tiempo libre una gran oportunidad de ayudar a los demás y de encontrar sentido a la vida. Además, comprender que casi cualquier actividad interesante puede ser tomada lo suficientemente en serio como para generar la sensación de competencia que aportaba el trabajo es un objetivo adecuado para la educación para el ocio. De hecho, los antiguos ideales del tiempo libre que le atribuían valores para perfeccionar el carácter han sido recientemente asociados con características tales como el conocimiento de uno mismo, el compromiso emocional y la auto-apropiación completa de una actividad, la inmersión del yo en la actividad, un sentido de la transformación personal asociado con él y la incorporación de la actividad en la memoria y el relato personal de un individuo (ver, Cuenca, 199x; 200x; Monteagudo-Sanchez, 2008). Además, el trabajo y otras actividades productivas puede vivirse de una manera rela- ification of rest and pleasure that is earned only with work. This is a vestige of western Judeo-Christian heritage and the Protestant Work Ethic that has influenced even predominantly Catholic countries in the Western hemisphere since the Industrial Revolution. Without work, and even if it follows work, leisure is suspect....seen as trivial and unimportant in its own right, as frivolous, non-productive activity where productivity is still the standard of worth. If retirement is feared and met with the apprehension of a lack of worthwhile, respectable work activity, then leisure is clearly not the answer. For many, leisure education would require becoming disabused of this idea, that worth is only in productivity and that unearned relaxation and gratification is valueless. For still others a compromise would be found through learning that free time can indeed be used in innumerable "productive" ways, in part-time paid and donated (volunteer) work in making things for others and in continuing to find in leisure the opportunities to be serious about meaning-making and personal contribution. Furthermore, understanding that nearly any interesting activity can be taken seriously enough to generate the sense of competence that work provided is an appropriate objective for leisure education. Indeed the ancient ideals of leisure that specified its values for the refinement of character have been more recently associated with such characteristics as self-awareness, emotional engagement, and complete self-appropriation of an activity, the lodging of self within the activity, a sense of personal transformation associated with it and the incorporation of the activity into the memory and personal narrative of an individual (Cuenca, 1996; 2000; MonteagudoSanchez, 2008). Furthermore, work and other productive activities can be embraced in a leisurely way, done voluntarily, at one's own pace and with an appreciation for 
jada, hacerse de manera voluntaria, al propio ritmo y apreciando lo que tienen de agradables. Por último, existe la conciencia de que el ocio también tiene que ver con renunciar a esas necesidades de logros visibles y con disfrutar y apreciar lo que está simplemente a nuestra disposición en los entornos físicos y sociales que nos rodean. Este significado del ocio se aprecia mejor en las palabras de uno de los escritores que mejor han escrito sobre el tema, Josef Pieper (1963):

"El ocio es...una actitud de no actividad, de calma interior, de silencio; significa no estar "ocupado, sino dejando que las cosas sucedan [...] El ocio no es la actitud mental de aquellos que intervienen activamente, sino de quienes están abiertos a todo... de aquellos que aflojan las riendas y que se liberan y relajan ellos mismos".

Este puede ser el significado del ocio más difícil de asumir por quienes están imbuidos de la ética del trabajo protestante, pero al decir de algunos, es una de las claves de lo que Tornstam denomina "gerotranscendencia", cuando la conciencia aprende a estar más centrada en el momento y menos dependiente de la producción o la acumulación. Otros gerontólogos han reconocido la dificultad de esta transición y la tendencia de la gente a permanecer ocupada y activa para olvidarse de los pensamientos de pérdida y de la proximidad de la muerte, de la sensación de no servir para nada y de una existencia sin objetivo (Ekerdt; Katz et al).

Por lo tanto, el ocio se conceptualiza mejor como una dialéctica de compromiso y desconexión que puede florecer mejor en la vida tardía cuando puede liberarse de su dependencia del significado del trabajo. La libertad que da el ocio permite tanto la expresión del propio yo en nuevas direcciones, como el cultivo de las relaciones con los demás, liberándose al mismo tiempo de la convención social y de las expectativas de productividad what about it is enjoyable. Finally, though, there is the awareness leisure is also about letting go of such needs for visible accomplishment in some sense and enjoying and appreciating that which is just available in the social and physical worlds that we are surrounded by. This meaning of leisure is best reflected in the words of one of the most compelling writers on the subject, Josef Pieper (1963):

Leisure is ....an attitude of non-activity, of inward calm, of silence; it means not being 'busy, but letting things happen." ..."Leisure is not the attitude of mind of those who actively intervene, but of those who are open to everything ...of those who leave the reins loose and who are free and easy themselves."

This may be the most difficult of all leisure meanings to embrace for those imbued with the Protestant work ethic, but in the view of some, it is one of the keys to what Tornstam calls "gerotranscendance," where consciousness changes to be more centered in the moment and less dependent on production and accumulation. Other gerontologist have recognized the difficulty of this transition and the tendency of people to stay busy and active primarily to be distracted from thoughts of loss and pending mortality, feelings of worthlessness, and an aimless existence (Ekerdt, Katz et al).

Leisure is thus best conceptualized as a dialectic of engagement and disengagement that may have its best flourishing in later life where it can be liberated from its dependence on the meaning of work. The freedom of leisure allows both for the natural expression of self, even in new directions, and the cultivation of community with others, while also freeing it from social convention and expectations of productivity and allowing the further culti-

[ 152 ] • Douglas A. Kleiber, Fernando Bayón Martín y Jaime Cuenca Amigo

SIPS - PEDAGOGIA SOCIAL. REVISTA INTERUNIVERSITARIA [1139-1723 (2012) 20, 137-176] • TERCERA EPOCA 
y permitiendo un mayor cultivo del significado que se deriva de la apreciación, gratitud y comprensión. Reconstruir el ocio en estos términos, abordándolo de forma personal, sería el foco esencial de una educación para el ocio.

\subsection{Preparación inadecuada para aprovechar el tiempo libre después de la jubilación}

En el estudio realizado por Robert Weiss, había una variación considerable en cuanto a la atención prestada a la jubilación antes de que ésta se produjera. Algunos evitaban cuidadosamente el tema aunque la llegada de la jubilación fuera inminente. Esto se puede producir incluso en casos en los que la jubilación es obligatoria, cuando no depende de una decisión del individuo. Algunas personas se preparan ellas mismas para su vida después del trabajo, y otras no lo hacen en absoluto. Sin embargo, las pruebas que presentan Weiss (2005) y otros, por ejemplo Feldman (2003), es que la preparación tiene un efecto positivo sobre la vivencia de la jubilación y el bienestar durante la misma, a pesar de que las circunstancias cambien un tanto. Pero, aunque se tenga controlada la economía, la forma de vida y la salud, optimizar la jubilación exige más atención a cuestiones sobre el estilo de vida y las fuentes del bienestar.

La imagen que prevalece del tiempo libre en la vejez, junto a una visión un tanto limitada del trabajo, es responsable en muchos casos de la falta de preparación para la jubilación. Como hemos observado, las pruebas existentes sugieren que la jubilación raramente resulta traumática y que es recibida por lo general, y al menos al principio, con algún entusiasmo por la mayoría. Con todo, aunque sean muchos los que están contentos por haber dejado de trabajar, son pocos quienes aprovechan su tiempo libre para optimizar sus vidas durante la jubilación. Incluso en los casos en que la transición se hace mejor, vation of meaning derived from appreciation, gratitude and understanding. Reconstructing leisure in these terms, dealing with them in personal ways, would be an essential focus of leisure education.

2.5. Inadequate preparation for making the most of free time after retirement

In the study done by Robert Weiss, there was considerable variation in how much attention retirees gave to their retirement in advance. For some, the subject was studiously avoided even if the time of retirement was clear and imminent. This may even be truer in the cases where retirement is mandatory, when it does not depend on a decision of the individual. Some prepare themselves for life after work and others do not. Weiss' (2005) evidence and that of others e.g. Feldman, (2003) however, is that preparing does have a positive effect on retirement adjustment and happiness with retirement, even if circumstances change somewhat. But even where there is some attention to finances, living arrangements and health, optimizing retirement requires more attention to questions of lifestyle and sources of well-being.

The view of leisure in later life that prevails -as well as a somewhat limited view of work- is largely responsible for the lack of preparation for retirement in many cases. As we have noted, the available evidence is that retirement is rarely traumatic for people, and is mostly greeted, at least initially, with enthusiasm for most. Still, if many are happy to be finished with work, too few take advantage of their free time to optimize their lives in retirement. Even in the best transitions there is often a disillusionment period that follows the initial good feeling. For these people, as well as those who struggle from the beginning, misperceptions about the opportunities re- 
suele existir un periodo de desilusión tras la sensación de bienestar inicial. En el caso de estas personas, así como para quienes se sienten deprimidos desde un principio, suelen tener una gran responsabilidad los malentendidos con respecto a las oportunidades relacionadas con el trabajo, el tiempo libre y uno mismo. Abogamos, por lo tanto, por un proceso educativo que incluya una evaluación más precisa e integral del valor del trabajo y el tiempo libre respectivamente, y que no deje de tener en consideración la importancia de la gestión de la economía, la salud y los bienes, que suelen ser las preocupaciones más comunes tanto de las personas a título individual cuanto de los programas de preparación para la jubilación. Hay ciertas pruebas en España que nos permiten ser optimistas: la actual generación de jubilados muestra una actitud más activa con respecto a la preparación de la jubilación que la anterior, al menos en algunas regiones (Sáez Narro; Aleixandre y Meléndez, 1996).

Los problemas suelen tener menos que ver con la gestión de los recursos que con la toma de decisiones con respecto a las oportunidades existentes. El tema de la gestión del tiempo es una parte habitual de los programas de prejubilación, pero muy a menudo adopta la forma de una mera administración del mismo durante las ocupadas vidas laborales -es decir, cómo ser eficiente con el poco tiempo del que se dispone. El problema de la gestión del tiempo en la jubilación tiene que ver con cómo utilizar mejor lo que en algunos casos es una abundancia de tiempo. Recomendamos que se planifique la jubilación teniendo en cuenta cómo afectarán las opciones que se adopten al bienestar durante la vida tardía, y para ello resulta importante comprender nuestra teoría y las pruebas que existen acerca del impacto sobre nuestra vida como jubilados de las actividades que pensamos desarrollar. lated to work, leisure and self are largely responsible. A case is thus made for an educational process that includes a closer, more thoughtful evaluation of work and leisure and their value as well as the usual consideration of the management of finances, health and property, which are the usual concerns of both individuals and retirement preparation programs. There is some evidence in Spain that let us be optimistic about this: the current generation of retirees shows a more active attitude towards retirement preparation than the previous one, at least in some regions (Sáez Narro, Aleixandre y Meléndez, 1996).

The problems frequently have less to do with the management of resources than the decision making with respect to opportunities. The subject of time management is a regular part of pre-retirement programming, but it all too often takes the form of time management in the course of busy work lives - that is, how to be efficient with the limited time available. The time management problem with retirement is how to best utilize what in some cases is an abundance of time. We suggest that retirement planning be done with a consideration of how those choices may matter to well-being in later life, and for that question it becomes important to understand our best theory and evidence about the impact of activity choices in later life.

[ 154 ] Douglas A. Kleiber, Fernando Bayón Martín y Jaime Cuenca Amigo SIPS - PEDAGOGIA SOCIAL. REVISTA INTERUNIVERSITARIA [1139-1723 (2012) 20, 137-176] • TERCERA EPOCA 
2.6. El poder del ocio para mejorar la vida durante la jubilación

Puede que las actividades de ocio que la gente suele buscar durante la jubilación no sean las que gozan de más prestigio. Y con todo, cualquier clase de relajación puede tener un efecto inmediato para reducir el persistente estrésrelacionado-con-el-trabajo que puede haber constituido una amenaza tanto física como psicológica. Y el hedonismo asociado con la gratificación inmediata puede ser un bienvenido alivio cuando ésta se ha ido posponiendo continuamente. Las consecuencias psicológicas de los estados emocionales positivos (desarrollados por ejemplo por la risa y la diversión) han demostrado no sólo mejorar el ánimo y ayudar a hacer frente al estrés y la pérdida, sino que también tienen el efecto de cambiar los criterios cognitivos hasta el punto de ampliar las perspectivas que intervienen en la toma de decisiones y en la resolución de problemas (Fredrickson, 2001, 2003).

Se suele reconocer el valor del ocio para reducir el estrés y generar placer, aunque sus beneficios psicológicos no siempre reciban el crédito que merecen, debido una vez más al efecto de los constructos sociales según los cuales la búsqueda de placer es una pérdida de tiempo, degenerativa en el peor de los casos, y recuperativa para regresar al trabajo en el mejor. Pero la tendencia a utilizar el tiempo libre para comprometerse ha sido reconocida por los gerontólogos como fundamental para envejecer de forma saludable y exitosa (por ej. Chiriboga \& Pierce, 1993; Dupuis \& Smale, 1995; Menec, 2003; Mishra, 1992; Nimrod, 2008; Weiss, 2005). Y aunque algunos consideran las clases específicas de actividades que son "productivas" -constructivas y similares al trabajo- o socialmente integradoras como las únicas que son realmente importantes (por ejemplo, Rowe \& Kahn, 1996), hay pruebas de que cualquier clase de compromiso que utilice y cree capacidades, tiene el efecto de aumentar el bienestar al aportar un sentido de
2.6. The power of leisure in enhancing later life

The leisure that people typically seek in retirement may not be the kinds of leisure that are most influential. Still, relaxation of any kind may have an immediate value in reducing at the enduring work-related stress that has been both physically and psychologically threatening. And the hedonism associated with immediate gratification may be a welcome relief when gratification has been steadily deferred. The psychological consequences of positive affect (e.g. in fun and mirth) has been shown to not only enhance mood and contribute to coping with stress and loss, it actually has the effect of changing cognitive sets to the point of broadening perspectives that help in problem- solving and decision-making (Fredrickson, 2001, 2003).

The stress-reducing and pleasure-generating value of leisure is generally recognized even if its psychological benefits are not always given the credit they deserve, again the effect of general social constructions of pleasure-seeking as a waste of time, degenerative at worst, and recuperative for returning to work at best. But the inclinations for using free time for engagement have been recognized by gerontologists as critically important to healthy and successful aging (e.g. Chiriboga \& Pierce, 1993; Dupuis \& Smale, 1995; Menec, 2003; Mishra, 1992; Nimrod, 2008; Weiss, 2005). And while some look at specific kinds of activity that are "productive" - work-like and constructive - or social integrative as the only ones that are truly important (e.g. Rowe \& Kahn, 1998), there is evidence that any kind of engagement that uses and builds capacities, has the effect of enhancing well-being by contributing to a sense of competence and strengthening one's general functional fitness (See Adams, Leibrandt \& Moon, 2011 for a review). Fur- 
competencia y al reforzar la capacidad funcional general de una persona (vid. Adams, Leibrandt \& Moon, 2011, para un análisis). Además, cuando se toma una actividad lo suficientemente en serio como para que una persona persista en sus esfuerzos por mejorar y avanzar y uno se va identificando con otras personas que comparten nuestro interés por una actividad, el resultado es el desarrollo de una "comunidad de competencias" que proporciona una sensación de identidad social y de pertenencia (cf. Stebbins, 1992; 2001).

Sin embargo, ese "ocio serio" puede seguir careciendo de actividad productiva, si entendemos ésta según los resultados valorados por la sociedad y si es simplemente algo compartido por un grupo de aficionados, como suele pasar con muchos deportes, aficiones y actividades al aire libre, como la caza y la pesca. Pero en algunos casos, caza y pesca incluidas, o realizar objetos como prendas de vestir, alfombras, jardinería o muebles, el resultado es un producto que suele ser comercializable. Si estas actividades se convierten en crematísticas pueden perder su motivación intrínseca como actividades de ocio, pero la mayoría de personas que realizan estas prácticas en el contexto del ocio, insisten decididamente en que disfrutan del "trabajo" y de hacerlo con una frecuencia que mantiene su sentido de libertad, independencia y control sobre el ritmo de la actividad.

Esta misma cuestión puede plantearse con respecto a las actividades de voluntariado, tal vez con más razón aún al tratarse de actividades productivas y no de ocio. Aunque por lo general son altruistas, las actividades de voluntariado no son necesariamente divertidas, salvo por la satisfacción asociada a la ayuda o contribución personal. Pero ello se ve de forma más clara en la realización de, al menos, algún aspecto de una actividad destinada a alcanzar algún fin. En otras palabras, el voluntariado tiene claramente motivaciones extrínsecas. Pero se hace durante el tiempo libre, voluntariamente y puede estar lleno de signi- thermore, when activities are taken seriously enough to lead a person into persisting with his/her efforts to improve and progress and into identifying with others with an abiding interest in the activity, they result in the development of a 'competence community' that provides a sense of social identity and place (Stebbins, 1992; 2001).

Such serious leisure may still fall short of productive activity, however, as defined by outcomes that are valued by society if they are simply shared by a group of aficionados, as is true of many sport and hobby activities and outdoor activities like hunting and fishing. But in some cases, including hunting and fishing, but also in making things, such as clothing, rugs, garden produce, or furniture, the result is a product that is often marketable. If these activities become income-producing activities they may lose their intrinsic motivation as leisure activities, but for most who produce such things in the context of leisure, they insist on enjoying the "work" and working at a pace that maintains their sense of freedom and independence and control over the pace of activity.

This same question can be raised about volunteer activities, maybe with a stronger case for them being productive activities but not leisure activities. Though they are generally altruistical, volunteer activities are not necessarily enjoyable except in the sense of satisfaction associated with helping or contributing. But that comes most clearly in the completion of at least some aspect of the activity en route to the meeting of some goal. In other words, it is more clearly extrinsically-motivated. But it is done during free time, is done voluntarily and can be meaningfully self-expressive, the criteria usually associated with leisure. In any case, there is strong evidence that volunteerism of any kind is associated with subjective well-being in later life (Musick y Wilson, 2007) and even with physical

[ 156 ] Douglas A. Kleiber, Fernando Bayón Martín y Jaime Cuenca Amigo

SIPS - PEDAGOGIA SOCIAL. REVISTA INTERUNIVERSITARIA [1139-1723 (2012) 20, 137-176] • TERCERA EPOCA 
ficado y auto-realización, criterios generalmente asociados al ocio. En cualquier caso, existen sólidas pruebas de que el voluntariado de cualquier tipo está asociado al bienestar subjetivo en la tercera edad (Musick \& Wilson, 2007) e incluso con la salud física. Encaje o no en la limitada definición del ocio, se trata claramente de una actividad deseable que contribuye al bienestar a muchos niveles. Y en especial, cuando se utilizan capacidades asociadas con el antiguo trabajo en un marco de voluntariado, también se puede experimentar un sentido de competencia y de valía. Debería resultar evidente, entonces, que las actividades de ocio pueden satisfacer muchas de las necesidades asociadas a los antiguos trabajos. El ejemplo de Weiss de una "buena jubilación" en su muestra (2005) era la de un hombre de negocios convertido en trabajador de la madera. Hizo cursos en cuanto tuvo la oportunidad y obtuvo al menos tanto como lo que invirtió en su antiguo trabajo. Se entregó de lleno y, por lo tanto, adquirió una nueva estructura vital, aunque siguió controlando su tiempo. La buena salud y los medios económicos adecuados también ayudaron, así como una buena relación con su mujer, que apreciaba su dedicación al trabajo de la madera, aunque ello les hiciera estar mucho tiempo separados. Pero lo que hay que observar en este caso es que trabajar la madera era un interés que se había desarrollado antes de la jubilación. De hecho, en el estudio de Weiss aquellos que probaron hobbies por primera vez después de la jubilación tenían menos probabilidades de mantener el interés por ellos.

Por último, existen esas personas, relativamente raras, que adoptan a tiempo una forma de vida auténticamente diferente basada en el ocio. Aunque encuentran formas de mantener el compromiso y utilizan sus capacidades cuando pueden y cuando les resulta gratificante, no sienten la necesidad de demostrar su valía siendo productivos y manteniéndose ocupados. Se pueden permitir a sí mismos el tipo de ocio al que se refería Pie- health. Whether it fits the narrower definition of leisure, it is clearly a desirable activity that contributes to well-being on many levels. And especially where capacities associated with former work are applied in the volunteer setting, they also maintain a sense of competence and worth. It should be obvious, then that leisure activities can meet many of the needs associated with former jobs. Weiss's choice of a "good retirement" from his sample (2005) was a businessman-turned-woodworker. He took courses at his earliest opportunity and got at least as invested in that as he did in his former work. He was committed to it and was thus determined by its structure; but nevertheless he remained in control of his time. Good health and adequate finances were foundational as well as a good relationship with his wife who appreciated his investments in woodworking even though they made for much separate time. But what should be recognized in this case is that woodworking was an interest that was developed before retirement. Indeed, in Weiss' study those who tried hobbies for the first time after retirement were far less likely to be sustain an interest in them.

Finally, though, there are those relatively rare individuals who embrace a truly different more leisure-based way of living in time. While they find ways to be engaged and use their capacities when they can and it feels self-expressive, they feel free of the need to demonstrate their worth by being productive and staying busy. They afford themselves the kind of leisure that Pieper spoke of in "letting the reins loose" and appreciating what the freedom of retirement affords. Indeed, the reflection and ego-integration that Erikson (1962) associated with this final stage of life may depends to a good degree on learning to relax, let go, and find the peace of leisure with fewer expectations of living up to some set of standards.

LA EDUCACION PARA EL OCIO COMO PREPARACION PARA LA JUBILACION EN... [ 157 ] SIPS - PEDAGOGIA SOCIAL. REVISTA INTERUNIVERSITARIA [1139-1723 (2012) 20, 137-176] - TERCERA EPOCA 
per como "aflojar las riendas" y apreciar lo que les aporta la libertad de la jubilación. De hecho, la reflexión e integración del yo que Erikson (1962) asociaba con esta etapa final de la vida puede depender en gran medida de aprender a relajarse, aflojar las riendas y encontrar la paz en el tiempo libre olvidándose de estar a la altura de ciertas normas productivistas preestablecidas.

Tal vez, este sería el mejor tipo de ocio para la cuarta edad. El ocio de la tercera edad, inmediatamente después de la jubilación, suele requerir más compromiso y crecimiento continuado, y al estar más cercano al fin del trabajo, puede funcionar mejor si reconstruye lo mejor de la vida laboral que se ha abandonado. Sin embargo, en cualquier caso, puede ser necesario efectuar cierto cambio de actitud. Puede sonar como una contradicción decir que el tiempo libre de la jubilación se optimiza ofreciendo nuevas formas de trabajar; de hecho, requiere volver a considerar lo que el trabajo aporta de forma natural al desarrollo humano (cf. Freedman, 1999) y cómo el tiempo libre complementa y permite la reconstrucción del trabajo y el esfuerzo de esa manera. El ocio es esencialmente una oportunidad de hacer lo que uno más desea, pero si ello implica cierto tipo de trabajo, debería ser el trabajo lo que aporte significado y disfrute. Ello requiere que uno llegue a ver la complementariedad del trabajo y el ocio en lugar de su viejo antagonismo.

Hay pruebas considerables de que la calidad en la vida tardía aumenta por y a través de las actividades de ocio o puede que consista en el propio ocio. Según algunos, el tiempo, la libertad que procura el ocio, es el principal beneficio de la jubilación (cf. Weiss, 2005). Pero las actividades, ya sean estructuradas o no estructuradas, ofrecen muchos beneficios como respuesta a las cuestiones que surgen más frecuentemente frente a la jubilación: qué debería hacer ahora; qué merece la pena hacer a nivel personal; de dónde puedo obtener significado y sentido de logro;
Perhaps, however, that would be the best of leisure for the fourth age. The leisure of the third age, immediately after retirement, is more likely to require engagement and continued growth, and, being close to the termination of work, it may work best if it reconstructs the best of that work life. Nevertheless, some attitude change is likely to be necessary in any case. It may sound like a contradiction to say the leisure of retirement is optimized in offering new ways to work; indeed it requires a reconsideration of what work most naturally contributes to human development (Freedman, 1999) and how leisure complements and affords a reconstruction of work and effort in that way. Leisure is essentially an opportunity to do what one most wants to do, but if that involves work of some kind, it should be work that brings meaning and enjoyment. This requires that one comes to see the complementarity of work and leisure rather than its antagonism.

There is considerable evidence that the quality of later life is enhanced by and through leisure activity and maybe simply leisure itself. The time, the freedom of leisure is the first benefit of retirement according to some (cf. Weiss, 2005). But activities, both structured and unstructured, offer many benefits directly in response to the questions that arise most commonly in the face of retirement: what should I do now; what is most personally worth doing; where can I derive meaning and a sense of purpose; and what will protect my health for the years to come (Antonovsky y Sagy, 1990). Physical activities such as swimming, jogging, gardening, and cycling clearly benefit physical health and may contribute - simply as structured activities — to mental health as well, especially as they require some degree of competence and connect one with others (Adams et al, 2011).

[ 158 ] Douglas A. Kleiber, Fernando Bayón Martín y Jaime Cuenca Amigo

SIPS - PEDAGOGIA SOCIAL. REVISTA INTERUNIVERSITARIA [1139-1723 (2012) 20, 137-176] • TERCERA EPOCA 
qué será bueno para mi salud en los años venideros (Antonovsky \& Sagy, 1990). Las actividades físicas como nadar, correr, la jardinería y el ciclismo benefician evidentemente a la salud y pueden ayudar también -simplemente como actividades estructuradasa la salud mental, especialmente cuando exigen cierto grado de competencia y de relación con los demás (Adams et al, 2011).

\section{El estado actual de los programas de pre- paración para la jubilación}

En Estados Unidos, los programas de preparación para la jubilación han tenido una existencia accidentada. Según Weiss (2005) y otros, sólo han tenido un éxito moderado a la hora de adaptarse a la jubilación, y su impacto ha tenido más que ver con los periodos iniciales de la jubilación que con los posteriores, y han tenido más que ver con la planificación práctica que con el ajuste (Glamser \& DeJong, 1975; Glamser, 1991; Reitzes \& Mutran, 2004; Taylor, M.A. \& Doverspike, D., 2003). Glamser no encontró de hecho ningún efecto de esos programas en el ajuste posterior. Sin embargo, su falta de eficacia puede estar relacionada con su más bien limitado foco en asuntos económicos y de salud y por su inadecuada atención al estilo de vida y fuentes de satisfacción continua. Feldman (2003) insiste en que existen abundantes pruebas de que el "asesoramiento" para la jubilación ha tenido impacto al (a) reducir la ansiedad relacionada con la inseguridad económica y (b) proporcionar una oportunidad de hacerse a la idea de la jubilación y tomar alguna medida con respecto a ella -"por ej., empezar un nuevo hobby”- (Feldman, 2003; 100). Pero añade que siguen sin resolverse las cuestiones sobre la duración efectiva, calidad percibida y relativo énfasis en los diferentes componentes.

Con respecto al contexto de tales programas, se han creado principalmente en tiempos de bonanza económica en marcos corpo-
3. The state of the art in retirement preparation programs

In the United States, retirement preparation programs have had a checkered existence. According to Weiss (2005) and others they have only been moderately successful in impacting adaptation to retirement, and those impacts have had more to do with earlier periods of retirement rather than later periods, and more to do with practical planning rather than adjustment (Glamser \& DeJong, 1975; Glamser, 1991; Reitzes \& Mutran, 2004; Taylor, M.A. \& Doverspike, D. (2003). Glamser in fact found no effects of such programs on subsequent adjustment. However, their lack of effectiveness may have had more to do with their rather limited focus on financial and health matters and inadequate attention to lifestyle and sources of continuing satisfaction. Freedman (2003) insists there is good evidence for retirement "counseling" having an impact by (a) reducing anxiety related to financial insecurity and (b) providing a chance to get used to the idea of retirement and make appropriate provision for it ("e.g. taking up a new hobby," p. 100), (Feldman, 2003). But he adds that questions about the effective length, perceived quality, and relative emphasis on different components remain to be addressed.

With respect to the context of such programs they have been created primarily in good economic times in corporate settings to facilitate and encourage older workers in making a successful transition to retirement. Indeed, they are arguably more about moving workers out of the workplace so that they can be replaced by younger, presumably more competent, but definitely more affordable workers. This of course would be more likely to occur in optional retirement settings, where the choice to retire might be 
rativos para facilitar y animar a los trabajadores más mayores a realizar una buena transición hacia la jubilación. De hecho, tienen más que ver con suprimir trabajadores de los centros laborales para poder reemplazarlos por otros, presumiblemente más jóvenes, pero sobre todo más baratos. Esto, desde luego, tendría más posibilidades de producirse en entornos donde la jubilación es opcional, donde la opción de retirarse puede depender de una imagen más clara de los beneficios y del alivio del estrés relacionado con la transición. De hecho, mitigar las preocupaciones financieras es parte del objetivo y los programas suelen estar acompañados de incentivos financieros que se pueden cobrar antes de lo que se esperaba. Además de las empresas, otros proveedores de programas de prejubilación son los servicios de planificación financiera y empresas de inversión que obtienen beneficios de la asistencia que proporcionan a los potenciales jubilados que están preocupados por su seguridad financiera y protección económica cuando dejen de tener ingresos fijos.

Los intereses más generales de los empleados, como las cuestiones de salud y vivienda, también están incluidos por lo general en esos programas, ya que tienen implicaciones concretas para la gestión financiera. Es menos común que se incluyan cuestiones familiares y matrimoniales así como la gestión del tiempo libre y las oportunidades que ofrece el ocio (Moen et al, 2011). De manera ocasional, se llama a especialistas en estas áreas para que colaboren en la programación, aunque sean gestionadas de manera bastante frecuente en los departamentos de recursos humanos de las empresas o de las firmas de inversiones financieras. Sin embargo, cuando el mercado ha entrado en crisis, estos elementos adicionales son los primeros en ser suprimidos y los programas de prejubilación pasan a ser considerados como las actividades más caras de la empresa.

En países con edad de jubilación preestablecida, como España, la situación es ligeramente diferente. Por un lado, en España la ju- dependent upon a clearer picture of the benefits and the alleviation about stress related to the transition. Indeed, the reduction of financial concerns is part of the purpose and the programs are often accompanied by financial incentives to retire earlier than might have been expected. Besides the corporation, a second proponent and provider of pre-retirement programs are the financial planning services and investment firms who stand to profit in the assistance they provide prospective retirees who are concerned about their financial security and wealth protection in the absence of a steady wages.

Arguably, though, the broader interests of the employee are considered in such programs as matters of health and housing are generally included as well since they have particular implications for financial management. Less commonly, marriage and family matters and the management of free time and leisure opportunities are incorporated (Moen et al, 2011). Occasionally, experts from these areas are called in to help with the programming although it is managed rather consistently within human resources divisions of organizations or financial investment firms. However, when the market has turned down, these additional pieces are the first to go and entire pre-retirement programs are likely to be seen as the most expendable of company activities.

In countries with mandatory retirement like Spain the situation is slightly different. On one hand, in Spain retirement is commonly seen and accepted as a social right at a mandatory age. Thus, nobody is tempted to interpret it necessarily as a sign of incapacity or lack of professional competence. Under this point of view, Spain (IMSERSO, 2000) is probably in a better position to fight against such a biases and stereotypes as:

[ 160 ] Douglas A. Kleiber, Fernando Bayón Martín y Jaime Cuenca Amigo

SIPS - PEDAGOGIA SOCIAL. REVISTA INTERUNIVERSITARIA [1139-1723 (2012) 20, 137-176] • TERCERA EPOCA 
bilación suele ser vista y aceptada como un derecho social a la edad establecida para hacerlo. Por lo tanto, nadie siente la tentación de interpretarla como un signo de incapacidad o de falta de competencia profesional. Según este punto de vista, España (IMSERSO, 2000) se encuentra probablemente en mejor posición para luchar contra prejuicios y estereotipos como: a) la jubilación y la vejez son sinónimos (esta comparación ha dejado hace mucho, desde luego, de ser válida); y b) la jubilación como una "situación final" o un "plazo señalado" (la jubilación es más un proceso, un periodo de transición que puede aportar muchas satisfacciones (ver, por ejemplo, Szinovacz, 2002a); todos los patrones de jubilación son los mismos (existen de hecho experiencias y secuencias vitales que son comunes a la mayoría de personas mayores) pero no hay ningún proceso de jubilación totalmente igual a otro (Bermejo García, 1969). Por otro lado, recientes declaraciones de grandes compañías de seguros de España, como MAPFRE, muestran que todavía queda mucho trabajo por hacer para alcanzar un nivel adecuado de compromiso personal para prepararse para la jubilación. La gente no suele por lo general ser tan proactiva en buscar información (relacionada con su situación financiera en el futuro, por ejemplo) como probablemente debería ser.

Las empresas españolas también muestran interés por "retirar" a los trabajadores más mayores para reemplazarlos por trabajadores más jóvenes y asequibles, y se debe reconocer que, a pesar de la edad de jubilación establecida por ley, tienen vías para poder hacerlo. No es en las empresas donde puede encontrarse una gran diferencia con respecto a la situación de Estados Unidos, sino en los trabajadores. Como no tienen que decidir individualmente si están "preparados" y/o deseosos de jubilarse, están menos dispuestos a prepararse para ese momento. De modo que puede decirse que la demanda de programas de preparación es inferior a la de Estados Unidos. Además, hay otra razón para a) retirement and old age as being synonymous (this comparison is today no longer valid); and b) retirement as a "final state" or a "deadline" (retirement is more a process, a transitional period which may include a lot of satisfactions (see, for example, Szinovacz, 2002a); all retirement patterns are the same (there are indeed experiences and life-sequences that are common to most seniors) but no retirement process is totally equal to another (Bermejo García, 1969). On the other hand, recent position statements by large insurances companies in Spain, like MAPFRE, show that in general there is still much work to do to achieve an appropriate level of personal commitment to preparing for retirement. People are not generally proactive in searching for information (in relation with their financial situation in the future, for example) as they probably should be.

Spanish Corporations also show some interest in "moving" retirees out of the workforce early, in order to replace them by younger and more affordable workers, and it must be acknowledged that, despite the mandatory age for retirement prescribed by law, there are ways in which they can do so. It is not from the side of corporations where a significant difference towards the situation in the United States can be found, but rather from the side of the workers. As they do not have to decide individually if they are "ready" and/or "willing" to retire, they are less inclined to prepare for that moment either. So it can be assumed the demand for preparation programs is lower than in the United States. Furthermore, there is another reason for the concern about retirement to be less acute in Spain: a very solid social welfare system saves the Spanish workers many worries about health care after retirement (since it is officially "public, free and universal") and 
que la preocupación por la jubilación sea menos aguda en España: un sistema de prestaciones sociales muy sólido ahorra a los trabajadores españoles muchas preocupaciones sobre la asistencia sanitaria después de la jubilación (dado que es oficialmente "pública, libre y universal") y garantiza a todos ellos una renta básica.

De hecho, no debe sorprendernos que en estas circunstancias, los primeros programas de preparación para la jubilación fueran una iniciativa del gobierno y no de las empresas privadas. Se organizaron por primera vez en la década de 1970 por el Instituto de Mayores y Servicios Sociales (IMSERSO), como una ampliación de las políticas públicas sobre jubilación y envejecimiento activo (Barrera, Malagón y Sarasola, 2008). Varias asociaciones, fundaciones y otras instituciones sin ánimo de lucro -a menudo financiadas por el gobierno- también desempeñaron un papel importante en el surgimiento de los programas de preparación para la jubilación en España. Es el caso de la Confederación Española de Aulas de la Tercera Edad (CEATE), que ha estado ofreciendo un programa para la preparación para la jubilación desde hace más de 25 años (Moragas, 2007).

Aunque los orígenes y los principales promotores de este tipo de programas en España deban encontrarse en los organismos públicos y organizaciones sin ánimo de lucro, el ambiente y la ética empresarial, así como cierto compromiso con los trabajadores, favorecieron que las empresas más sólidas -especialmente en mejores épocas económicaspudieran ofrecer dichos programas. La empresa eléctrica Unión Fenosa es especialmente conocida por organizar cursos para que sus empleados se preparen para la jubilación, con un alto nivel de calidad (Moragas, 2007).

El enfoque que se da al ocio en tales programas suele estar centrado en la gestión del tiempo- después de todo "habrá mucho más tiempo libre" - y sobre todo en la identificación de oportunidades de viajar. No existe guarantees all of them a basic income.

In fact, it is not surprising that, under these circumstances, the first retirement preparation programs in Spain were an initiative of the government and not of private companies. They were first organized in the 1970's by the Institute for Elder People and Social Services (Instituto de Mayores y Servicios Sociales: IMSERSO) as an extension of the public policies on retirement and active ageing (Barrera, Malagón y Sarasola, 2008). Several associations, foundations and other nonprofit organizations -often funded by the government- also played an important role in the emergence of retirement preparation programs in Spain. Such is the case with the Spanish Confederation of Classes for the Third Age (Confederación Española de Aulas de la Tercera Edad: CEATE), that has been offering a program for retirement preparation for more than 25 years (Moragas et al., 2007). Even if the origins and the main developers of this kind of programs in Spain are to be found among public agencies and nonprofit organizations, company morale and climate and commitment to the workers put the stronger companies - particularly in better financial times - in a position to offer such programs. The power company Unión Fenosa is especially well known for organizing courses for their employees to get prepared for retirement, at a high level of quality (Moragas, 2007).

The approach to leisure in such programs is typically addressed to the matter of time management - "there will be more of it" after all - and the identification of opportunities for travel in particular. There is nothing in the literature that we have been able to find to suggest a more careful consideration of the nature of work and leisure in such a program. Thus the suggestions that follow may be considered within the context of recommen-

[ 162 ] D Douglas A. Kleiber, Fernando Bayón Martín y Jaime Cuenca Amigo

SIPS - PEDAGOGIA SOCIAL. REVISTA INTERUNIVERSITARIA [1139-1723 (2012) 20, 137-176] • TERCERA EPOCA 
nada en la literatura que hayamos podido encontrar que sugiera una consideración más cuidadosa de la naturaleza del trabajo y del tiempo libre en ese programa. Por lo tanto, las sugerencias que vienen a continuación pueden ser consideradas dentro del contexto de recomendaciones para mejorar los programas de prejubilación en aras del bienestar en la vida del jubilado, reconociendo que los incentivos de las empresas y las firmas de inversión para proporcionar dichos servicios siguen siendo una cuestión pendiente.

\section{Estrategias en educación del ocio para programas de preparación para la jubilación}

Dadas las evidencias derivadas del estudio de Weiss (2002) y de otras fuentes, la justificación de los programas de preparación a la jubilación en general - desde el punto de vista del trabajador - radica en que la planificación marca una diferencia significativa en la adaptación a la jubilación, al menos en los primeros años. Por eso, centramos aquí nuestra atención sobre las estrategias de educación que se han usado con efectividad y otras que deberían probarse para mejorar el impacto de dichos programas a corto y largo plazo. La evidencia antes mencionada sobre el valor y la importancia del ocio en la adaptación y el disfrute de la tercera edad justifica la ampliación del contenido de dichos programas, de forma que incluyan actitudes hacia el trabajo y el ocio y oportunidades de retiro. Las estrategias de concienciación, de resolución de problemas y de toma de decisiones serían partes importantes del diseño del programa, al igual que la consideración de las diferentes circunstancias individuales.

\subsection{Evaluación de las diferentes circunstancias individuales}

La principal diferencia individual que debemos observar aquí es la de ser español o estadounidense y, en este sentido, la diferencia pri- dations for pre-retirement program improvements in the interest of later life well-being, recognizing that the incentives of corporations and investment firms to provide such services remain a question 4. Leisure educational strategies for retire-
ment preparation programs

Given the evidence from the Weiss (2005) study and elsewhere, the justification for preretirement programs in general -from the worker's perspective-is that planning makes a significant difference in adjustment to retirement, at least in the first few years. Thus we turn our attention here to the educational strategies that have been used effectively and others that should be tried to improve the short and long term impact of such programs. The evidence reviewed above about the value and importance of leisure in adjusting to and flourishing in later life, makes a case for the content of such programs be expanded to include attitudes toward work and leisure and retirement opportunities as well. Consciousness-raising, problems-solving and decision-making strategies would thus be important parts of program design, as would the consideration of individual differences in circumstances.

4.1. Assessing individual differences in circumstances

The greatest individual difference we are attending to here is being Spanish or American, and the primary difference there is in 
mordial radica en tener una edad de retiro obligatorio o la posibilidad de seguir trabajando hasta que uno decida lo contrario. Puede haber otras diferencias culturales que también merezcan nuestra atención, como la actitud a la hora de recibir consejos o las actitudes generales hacia el trabajo y el ocio, o las diferencias en el contexto social del retiro entre los dos países. Pero, aparentemente, las diferencias entre estos dos países no son tan significativas como sus diferencias con terceros y, quizá, sean mucho más importantes las diferencias dentro de cada país. Debido a una mayor diversidad en los patrones de retiro en los EE.UU., puede existir igualmente una mayor variedad en las circunstancias del mismo, aunque en ambos países la gente se distingue por el bagaje con que llegan a la jubilación. Estas diferencias deben estudiarse en la parte de evaluación de necesidades de cualquier programa.

\subsubsection{Salud}

Uno de los factores principales de diferenciación entre retiros es la salud. En algunos casos - en ambos países - la enfermedad y la discapacidad es un motivo de retiro prematuro, y en EE.UU. suele ser un factor limitador a la hora de seguir trabajando después de la edad típica de jubilación. Uno de cada ocho jubilados de Weiss presentaba algún tipo de discapacidad. Con relación a las actividades de ocio, puede observarse una restricción similar en las opciones tras la jubilación. La continuidad de una actividad física vigorosa puede estar contraindicada y las posibilidades de realizar actividades de aventura también podrían verse restringidas. Los problemas de salud pueden condicionar el ritmo de las actividades; sin embargo, si el pronóstico médico no es bueno, parece extenderse la ideología "podría ser recomendable hacer cuanto antes ese viaje soñado".

Por otro lado, el ocio debe ser considerado, en su conjunto, como una fuente de bienestar para los problemas de salud, como lo es en having a mandatory retirement age versus having the option to work longer. There are perhaps other cultural differences worthy of our attention as well, such as the receptivity to advice or general attitudes toward work and leisure or differences in the social context of retirement in the two countries. But, arguably, the differences between these two countries are less than their differences with other countries, and perhaps more important are the differences within each country. Because of more variability in retirement patterns in the US, there may be more variability in the circumstances of retirement as well, but in both countries people differ in what they bring to retirement. These differences must be addressed in the needs assessment part of any program.

4.1.1. Health

One of the more important factors that differentiate retirees is health. In some cases in both countries - illness and disability is a reason for early retirement, and in the US it often is the limiting factor in continuing to work past typical retirement ages. One in eight of Weiss's retirees had some kind of disabling condition. With respect to leisure activities, post retirement options may be similarly limited. Expanding vigorous physical activity may be contraindicated and the possibilities considered for adventurous activities can be similarly constrained. Health concerns may also dictate the timing of activities, however, and if the health prognosis is not good, taking that retirement trip sooner than later would be sensible.

On the other hand leisure should be fully examined as a restorative resource for health concerns as it is in earlier periods of life (see, for example, Kleiber et al, 2002)). If the health problem is overuse and stress related to work (e.g. arthritis in the hands that is exacerbated

[ 164 ] • Douglas A. Kleiber, Fernando Bayón Martín y Jaime Cuenca Amigo

SIPS - PEDAGOGIA SOCIAL. REVISTA INTERUNIVERSITARIA [1139-1723 (2012) 20, 137-176] • TERCERA EPOCA 
periodos anteriores de la vida (véase, por ejemplo, Kleiber et al, 2002). Si el problema de salud es el desgaste y el estrés relacionados con el trabajo (p. ej. una artritis en las manos agravada por el trabajo con el ordenador), el simple descanso de esa actividad puede suponer una mejoría. Pero las actividades alternativas pueden tener el efecto recuperador de una mejor salud. Los programas de ejercicio y flexibilidad, como Pilates y Tai Chi, pueden ser especialmente útiles a la hora de combatir una serie de problemas físicos; además, la realización de actividades en un contexto social sobre el que se tiene un mayor control puede ser muy importante para mejorar el estado de ánimo y reducir la depresión (Janke, Son \& Payne, 2009). Weiss observa que, sin embargo, para algunas personas no existía una enfermedad en sí, sino que era una sensación de declive físico con "connotaciones de mortalidad" (2002: 26), lo que les llevaba a retirarse.

\subsubsection{Naturaleza de la separación del trabajo}

Para algunas personas la separación puede ser dolorosa porque el trabajo era satisfactorio en el ámbito personal, además de una fuente de autoestima e identidad. Si la jubilación es obligatoria o ha sido impuesta de alguna manera, puede provocar sentimientos de futilidad e incluso un "amor no correspondido", si no se encuentra un sustituto adecuado. Para algunas personas, este sustituto puede ser un nuevo empleo - a tiempo parcial o completo - en el que se requieran sus capacidades, aunque estas opciones se consideran más comunes en EE.UU. que en España, donde el empleo después de los 65 años está muy restringido en la mayoría de los casos. El trabajo a tiempo parcial ("empleos puente" Weiss, 2002) puede ser una opción en EE.UU., mientras que, en ambos países, el voluntariado suele ofrecer la posibilidad de aplicar capacidades antes muy valoradas, sólo que ahora de modos más informales, en las que by typing), then simply the rest from that activity may be restorative. But alternative activities may have the effect of restoring better health. Exercise and flexibility programs such as Pilates and Tai Chi may be especially helpful in combating a variety of physical ailments; and doing activities in a social context over which one has more control may be significant for improving mood and reducing depression (Janke, Son \& Payne, 2009). Weiss noted that for some, though, it wasn't an illness, per se, but just a sense of physical decline -with "intimations of mortality" (2002: 26) - that pushed them to retirement.

\subsubsection{Nature of separation from work}

For some, the separation may be painful because the work was personally satisfying and a source of self-esteem and identity. If the retirement is mandatory or $\mathrm{co}^{-}$ erced in some way, this may result in feelings of worthlessness and even "unrequited love" if suitable substitutes aren't found. For some this may mean a new job - part or full time - where those skills are called upon, though such options are considerably more common in the US than in Spain where employment over the age of 65 is prohibited in most cases. Part time work ("bridge jobs" Weiss, 2002) may be an option in the US, whereas volunteer work in both countries often allow for the application of formerly valued skills in more leisurely ways, where there is an emphasis on enjoyment of the work and control of one's time or effort. Beyond that, many traditional leisure activities call 
se enfatiza el disfrute del trabajo, así como el control del tiempo y el esfuerzo propios. Más allá de eso, muchas actividades tradicionales de ocio requieren una amplia gama de capacidades relacionadas con el trabajo que podrían perderse.

Cuando el abandono de tareas y puestos relacionados con el trabajo no supone un problema, la oportunidad de desarrollar actividades completamente nuevas puede ser muy bien recibida (p. ej. Nimrod \& Kleiber, 2007). No obstante, no todo el mundo tiene una actitud de aprendizaje necesaria para tolerar las experiencias de un principiante $y$, de hecho, las actividades de ocio completamente nuevas tras la jubilación son llamativamente inusuales; a la luz de la realidad social, sería recomendable encontrar algo que se aproxime un tanto a las capacidades usadas en el trabajo, quizá una actividad que fuera satisfactoria en el pasado.

\subsubsection{Relación con los demás en el trabajo}

Los jubilados varían en su relación con los demás en el lugar de trabajo. Algunos no ven el momento de dejar los conflictos interpersonales, los resentimientos y el estrés asociados a la interacción con otras personas en el trabajo. Para otros, sin embargo, los compañeros de trabajo son como una segunda familia y la amistad creada puede durar toda la vida y será muy difícil sustituirla. En algunos casos, incluso imposible. Muchas amistades sobreviven a la jubilación, independientemente de si los amigos se retiran al mismo tiempo o no. Quizá, en muchos casos, la salida de compañeros de trabajo forma un cuadro mixto: acabar con algunas relaciones es un alivio mientras que la continuidad o la sustitución de otras es una prioridad. Y la idea de sustituir a amigos, o a segundas familias, puede ser particularmente difícil si el protagonista se muda de la localidad donde estaba su trabajo. Es el caso de quienes van a vivir a residencias para jubilados. Para ellos, la estructura institucional, a menudo segregada upon a wide variety of work-related skills that may be missed.

Where the abandonment of work-related roles and tasks is agreeable, the opportunity for entirely new activities may be particularly welcomed (e.g. Nimrod \& Kleiber, 2007). Still, not everyone may have the necessary learning stance to tolerate the experiences of a novice or beginner; finding something that approximates some of the skills used on the job, perhaps an activity that was satisfying in the past, would be advisable.

\subsubsection{Attachments to others at work}

Retirees vary in their attachment to others in the workplace. For some, leaving the interpersonal conflicts, resentments, and stresses associated with interacting with others on the job can't come soon enough. For others, however, co-workers are like a second family, and friendships formed may be lifelong and very difficult to replace if they must be replaced at all. Many friendships transcend retirement, whether or not the friends retire at the same time. Perhaps in most cases the departure from co-workers is a mixed picture; closing out some relationships is a relief while extending or replacing others is a priority. And the idea of replacing friends or second families may be particularly difficult if one moves away from the location of former work. But such is the case for some who move to retirement communities. For them the institutional structure - often age segregated is necessary to facilitate the creation of new friendships in place of those that have been

[ 166 ] Douglas A. Kleiber, Fernando Bayón Martín y Jaime Cuenca Amigo

SIPS - PEDAGOGIA SOCIAL. REVISTA INTERUNIVERSITARIA [1139-1723 (2012) 20, 137-176] • TERCERA EPOCA 
por edades, es necesaria para facilitar la creación de nuevas amistades que sustituyan a las que se han perdido con la jubilación y la mudanza. Este patrón parece ser mucho más común en EE.UU. que en España. No obstante, en ambos lugares la inversión en otras personas - familiares, amigos y otros integrantes de la comunidad, puede ser la mejor manera de recuperarse de una sensación de separación de los amigos cercanos del trabajo y reducir las perspectivas de aislamiento social. Weiss (2005) concluye su análisis con la sugerencia de que la mejor forma de compensar las pérdidas que supone el retiro es establecer nuevas conexiones con otros:

"Aunque el retiro puede suponer que nuestras energías, ambiciones o ímpetu para trabajar ya no están al nivel de las demandas del trabajo que solíamos hacer, eso no afecta a nuestra sabiduría o preocupación por los demás o a nuestro deseo de seguir contribuyendo a nuestro entorno social". (2005: 191)

Y añade que "si se me obligara a elegir, elegiría la contribución por encima del sosiego, aunque no son incompatibles" (op. cit).

\subsubsection{Personalidad y actitud}

La evidencia de cómo la personalidad durante la tercera edad afecta a la manera de preparar el ocio tras la jubilación no ha sido trabajada muy extensivamente; pero el estudio muestra de manera permanente que hay más estabilidad que cambio en la personalidad a lo largo de la vida y que, en la tercera edad "somos más auténticos” (McRae \& Costa, 1999). Por tanto, tiene sentido que la transición a la jubilación se gestione prestando atención a las diferencias individuales en la personalidad, en el buen entendimiento de que las inclinaciones que esta población puede mostrar hacia el compromiso con su tiempo libre estarán en consonancia con niveles mayores o menores de ciertas características de su personalidad, relinquished with retirement and moving to a different location. This pattern appears to be far more common in the US than in Spain. In both places, however, investing in others - family, friends and others in the community - may be the best way to recover from a sense of separation from close work friends and reduce the prospects of social isolation. Weiss (2005) ends his analysis with the suggestion that the losses of retirement are best redeemed in new connections with others:

"While retirement may mean that our energies or ambitions or zest for work are no longer up to the demands of the work we once did, this says nothing about our wisdom or concern for others or desire to continue to contribute to the social world". (2005: 191)

And he adds that "if pressed to choose, I would choose contribution over serenity; but there is no inconsistency between them" (Op. cit).

\subsubsection{Personality and attitudes}

The evidence on personality in later life is not extensive, but research consistently shows more stability than change in personality over the lifespan and that in later life "we become more ourselves" (McRae y Costa, 1999). It makes sense then that the transition of retirement would be managed with some attention to individual differences in personality and the understanding that inclinations people would have for free time involvement would be consistent with greater or lesser degrees of such characteristics as extraversion/introversion, openness to experience, and conscientiousness, these among the "Big 5" (McRae y Costa, 1999). Retirement programming 
tales como la extroversión/introversión, un carácter abierto a la experiencia y la concienciación, características que forman parte del grupo de las “5 grandes" (McRae \& Costa, 1999). La programación de la jubilación, de hecho, podría usar algún tipo de repertorio de la personalidad, con objeto de crear así una asociación entre él y los intereses individuales, como base para la sugerencia de que no hay una "única vía correcta" hacia el retiro y el ocio útil, y que es importante considerar cuidadosamente las inclinaciones personales.

En contraste con aspectos más estables de la personalidad, las actitudes pueden someterse a desafíos como parte del proceso educativo, especialmente en la medida en que las actitudes hacia el trabajo (en tanto que es valorable) y el ocio (en tanto que no lo es) predicen la infelicidad en los años posteriores a la jubilación. Aunque cabría argumentar que estos asuntos deben dejarse a los profesionales de la salud mental, los educadores de ocio pueden acudir a la plasticidad de la cognición y la maleabilidad de las actitudes aún existentes a edades avanzadas (Baltes \& Baltes, 1998), especialmente en el periodo inmediatamente siguiente a la jubilación, e invitar a un proceso educativo de revisión y reconsideración.

\subsection{Explorar las posibilidades, establecer prio- ridades y actuar}

Dado lo que se considera perdido al final del trabajo remunerado - estructura, relaciones, sensación de logro - la cuestión que se debe plantear en un programa de preparación para la jubilación sería: ¿son sustituibles? La respuesta es: sí. Pero sería importante que un cliente no considerara que se está produciendo esta sustitución o que la considerara como "ocio". Se trata, en gran medida, de decidir el mejor modo de pasar el tiempo adicional que suele seguir a la jubilación y abordar cuestiones como “¿Cuánta estructura necesito? y ¿por qué? ¿Se trata sólo de que, hasta ahora, tenía una estructura y ahora might indeed use some kind of personality inventory and then some association with interests as a basis for suggesting that there is no "right way" to retire and use leisure, and that it is important to consider one's inclinations carefully.

Attitudes, in some contrast with the more stable aspects of personality, could be challenged as a part of the educational process, especially to the extent that attitudes toward work (as valuable) and leisure (as not) predict unhappiness in the years following retirement. While it could be argued that such things are better left to mental health professionals, leisure educators can be reminded of the plasticity of cognition and the pliability of attitudes that is still available with aging (Baltes \& Baltes, 1998), especially in period just after retirement, and invite an educational process of review and reconsideration.

4.2. Exploring possibilities, setting priorities and taking action

Given that which is considered lost with the end of formal work - structure, relationships, a sense of achievement-the question to be asked early in a retirement preparation program would be: Are they replaceable? The answer is, Yes. But it would be important for a client to avoid considering such replacement as occurring as, or in, "leisure." It is largely a matter of deciding how best to spend some of the increases in time that typically follow retirement and addressing such questions as: How much structure do I need? and why? Is it just the fact that I have been structured

[ 168 ] Douglas A. Kleiber, Fernando Bayón Martín y Jaime Cuenca Amigo

SIPS - PEDAGOGIA SOCIAL. REVISTA INTERUNIVERSITARIA [1139-1723 (2012) 20, 137-176] • TERCERA EPOCA 
siento un vacío? ¿ $\mathrm{O}$ es que estoy habituado a trabajar $y$, por tanto, tengo que cambiar de hábitos?". Antes de la jubilación, el trabajo predefinido y estructurado ha librado al jubilado de tener que plantearse estas preguntas: “¿Qué vale la pena hacer? ¿Cuáles son los límites de mi desarrollo? ¿Dónde está el sentido?" Estas preguntas, más existenciales, identificadas por Antonovsky y Sagy (1990) como críticas en esta transición a la jubilación, proporcionan una información importante para los procesos de educación para el ocio, que se han venido usando en una serie de contextos distintos (véase Bullock, Mahon \& Killingsworth, 2011; Datttilo, 2008). En este artículo, hemos hablado en buena medida sobre entender el ocio y hemos revisado el proceso de evaluación de las necesidades; pero los elementos comunes a la educación para el ocio a todos los niveles son la conciencia propia y la determinación de valores, la identificación de recursos, la exposición, la resolución de problemas y la toma de decisiones.

\subsubsection{Conciencia propia y determinación de valores}

Hay muchas formas de realizar una verificación de valores, algunas de las cuales usan instrumentos estandarizados. Incluso hay versiones que se centran en los valores de ocio. Se basan en la parte de las preferencias de una persona relativamente bien formadas, en cierto sentido relacionadas con la personalidad, como una marcada preferencia por las situaciones sociales, estar con la familia, tener la manera de conseguir algo, tener emoción y aventura, o algún tipo de competición. Se pueden ponderar las propias preferencias de un modo que permita a los creadores de programas educativos para el ocio poder entenderlas con relación a otras, y que los jubilados pueden entenderse a sí mismos algo mejor.

Pero los valores cambian o, al menos, se reordenan dinámica y jerárquicamente en función de las circunstancias de la vida y, verdaderamente, pueden cambiar con la jubilación. and there is now a void? Or am I just in the habit of working, and thus have to change my habits? Prior to retirement, predefined and structured work has saved the retiree from having to ask the questions: What is worth doing? Where are my growth edges? Where is meaning? These more existential questions, those identified by Antonovsky \& Sagy (1990) as central to this retirement transition, provide important background for leisure education processes that have been used in a variety of other settings (Bullock, Mahon \& Killingsworth, 2011 ; Dattilo, 2008) We have talked about understanding leisure and reviewed the process of needs assessment above to some extent, but common to leisure education at all levels are self-awareness and value clarification, resource identification, exposure, problem solving and decision making.

\subsubsection{Self-awareness and value clarification}

There are many ways to do values verification some of them utilizing standardized instruments. There are even versions that focus on leisure values. They are based on that part of a person's preferences that are relatively well formed, in some ways related to personality, such as strong preference for social situations, to be with family, to have some way of achieving something, to have excitement and adventure, to have some kind of competition. People can weigh in on their preferences in a way that leisure education program providers can understand them relative to others, and the retirees can understand themselves a bit better.

But values are subject to change or at least to reprioritization based on life circumstances and may indeed change with retirement. By doing some reassessment of priorities and preferences, in comparison to the 
Al reconsiderar las prioridades y preferencias en comparación con el pasado, o con otras personas, el interesado se sitúa en una posición en la que considera las alternativas disponibles. Y, en la medida en que la educación para el ocio genera cierto cambio en los valores relacionados, por ejemplo, con el trabajo, es posible que se reordenen las prioridades.

\subsubsection{Identificación de recursos}

Como ya se ha observado, los que realizan programas de preparación para la jubilación suelen empezar por la identificación necesidades y recursos financieros, si estos están disponibles, lo que también tiene sin duda implicaciones en las oportunidades de ocio. La planificación de viajes, especialmente, suele considerarse dentro del contexto de lo que uno ha estado ahorrando y de si es un uso adecuado de fondos que son, inevitablemente, limitados. Los recursos financieros limitarán también otras actividades de ocio, por supuesto, pero en el curso de la identificación de recursos, deberían considerarse los propios recursos de ocio, incluyendo las instalaciones municipales de arte, cultura, voluntariado, deporte, huertos comunitarios, etc. Y, en la medida en que los demás pueden perfilar nuestros propios intereses, es importante revisar las oportunidades de instrucción y de una educación más general a este respecto.

Finalmente, la identificación de recursos sería una estrategia negligente si soslayara el reconocimiento de la persona en sí misma como el principal recurso. Puede parecer ilógico hasta que consideramos que las personas son, más o menos, capaces de disfrutar (véase Mannell, 1984) de sí mismos, constituyéndose en "una buena compañía para sí mismos”. Para ello se requiere cierto grado de conciencia de uno mismo, quizás también de autoindulgencia. Puede que sea necesario descubrir y cultivar, como en un creciente despertar de la conciencia, esa capacidad más plena para el esfuerzo tanto de relajación como de autorregulación. past or in comparison to others puts one in a position to consider available alternatives. And to the extent that leisure education leads to some change in values relative to work and leisure for example, reprioritization is likely to occur.

\subsubsection{Resource identification}

As noted earlier, those who do retirement preparation programming in later life generally start with the identification if financial resources needed and available, which also has implications of the leisure opportunities available. Travel planning especially is often examined within the context of what have you been saving for and whether that is an appropriate use of limited funds. Financial resources will limit other leisure activities as well, of course, but in the course of resource identification the leisure resources themselves should be considered, including community facilities for art, sport, community gardening, etc,. And, to the extent that new interests may be further shaped by others, it is important to review the opportunities for instruction and more general education about them.

Finally, resource identification would be remiss if there wasn't some recognition of the person him or herself as a resource. This may seem to defy logic until one considers that people are more or less capable of enjoying themselves (Mannell, 1984) and being good companions to themselves. Some degree of self-awareness is called for as well as self-compassion. A fuller capacity for both relaxation and self-regulated effort may need to be discovered and cultivated in a consciousness-raising way. 


\subsubsection{Exposición}

El mejor profesor del ocio, y de lo que ofrece, es, por supuesto, la experiencia directa. Puede que no sea factible para la preparación del retiro incluir "excursiones sobre el terreno" a eventos de ocio, pero sí que es razonable usar varios tipos de medios para obtener información sobre actividades y lugares de ocio y, quizás, usar casos prácticos de otras personas que participen en varias actividades. También podría haber simulaciones. Pero, en la medida en que el programa dura varios días o semanas, podrían asignarse actividades y debatir las experiencias.

\subsubsection{Resolución de problemas}

El estudio de los límites al/del ocio es una de las áreas de investigación más fértiles en los estudios del ocio (entre otras publicaciones, véase Jackson, 1999). Las limitaciones (barreras) pueden ser intrapersonales, interpersonales y estructurales. Las limitaciones intrapersonales incluyen la timidez o la ansiedad, por ejemplo. Son limitaciones interpersonales las asociadas con responsabilidades sociales y la falta de compañeros disponibles. Mudarse a una ciudad nueva limitaría la participación en algunas actividades debido a la falta de compañeros con los que planificarlas y participar en ellas. Las responsabilidades asistenciales, o tener personas dependientes a tu cargo, podrían limitar gravemente las opciones de ocio. Las barreras estructurales pueden incluir el coste de una actividad o la accesibilidad física de las instalaciones. Las barreras se superan mediante un proceso de "negociación de los límites". Existe una considerable evidencia de que la existencia de límites es común, pero que a menudo se superan mediante el interés en participar, lo que fuerza a un cambio en el estado de las cosas. Este proceso se materializa en estrategias cognitivas como la reordenación jerárquica de las opciones, y estrategias de conducta, como encontrar compañeros entre los participantes actuales en una actividad (véase Jackson, Crawford \& Godbey, 1992)

\subsubsection{Exposure}

The best teacher about leisure and what it offers is, of course, direct experience. It may not be very feasible for retirement preparation to involve "field trips" to leisure venues, but it does make some sense to use media of various kinds to provide information about activities and leisure places, and perhaps to use case studies of others involved in various activities. Simulations might also be available. But to the extent that the program lasts over multiple days or weeks, activities may be assigned and experiences discussed.

4.2.4. Problem solving

Research on constraints to leisure is one of the most fertile areas of investigation in leisure studies (among several reviews, see Jackson, 1999). Constraints (barriers) may be intrapersonal, interpersonal and structural. Intrapersonal constraints may have to do with shyness or anxiety, for example. Interpersonal constraints include those associated with social responsibilities and the lack of available partners. Moving to a new city would limit participation in some activities due to the lack of partners with whom to plan and participate. Caregiving responsibilities may severely limit leisure options. Structural barriers may include the expense of an activity or the physical accessibility of facilities. Barriers are overcome through a process of "constraint negotiation." There is considerable evidence that the existence of constraints is common, but that they are often overcome in the interest in participating. This takes the form of cognitive strategies, such as re-prioritizing of options, and behavioral strategies, such as finding companions from among those who currently engage in an activity (see, Jackson, Crawford \& Godbey, 1992)

LA EDUCACION PARA EL OCIO COMO PREPARACION PARA LA JUBILACION EN... [ 171 ] SIPS - PEDAGOGIA SOCIAL. REVISTA INTERUNIVERSITARIA [1139-1723 (2012) 20, 137-176] - TERCERA EPOCA 
Tras la evaluación de las necesidades, la determinación de valores, la exposición y la negociación de las barreras, la educación para el ocio puede seguir siendo importante en la toma de decisiones y la actuación y, en última instancia, en el compromiso con las prácticas. Es importante porque estos procesos no tienen lugar de forma lineal, sino que requieren experimentación y reconsideración. El intento de establecer una dirección para la implicación puede fracasar por una serie de razones, pero en la medida en que los factores que impiden un inicio o continuación exitosas son manejables, puede reiniciarse el proceso de negociación de los límites. Puede ocurrir que los constreñimientos en una dirección tengan la feliz consecuencia de llevar a una persona en otra dirección (Kleiber, McGuire et al, 2008). En cualquier caso, debemos recordar a los futuros jubilados la conclusión de Weiss en su libro sobre la experiencia de la jubilación: "Incluso en la jubilación - especialmente en la jubilación - siempre hay algo que hacer" (2008: 192).

Dicho esto, también es importante recordar a los jubilados una de las principales virtudes del ocio, y es la libertad de relajarse, de no "hacer nada", de abrir la mente a lo que ofrece el mundo sin necesidad de actuar sobre ello, de limitarse a "ser". Tomar simplemente la decisión de encontrar la paz en la propia existencia puede ser uno de los compromisos más importantes que puede adoptar una persona.

\section{Conclusión}

Si este examen de las realidades de la preparación para la jubilación en Estados Unidos y en España nos dice algo, es que en ambos países existe una necesidad significativa de una mayor preparación y que la incorporación de la educación para el ocio en esos programas está garantizada. Las diferencias entre los dos países en cuándo y cómo se produce la jubi-
Following needs assessment, value clarification, exposure, and constraint negotiation leisure education can continue to play a role in making decisions, taking action and ultimately in committing to activities. This is important because these processes do not occur in a linear fashion but require experimentation and reconsideration. The attempt to establish a direction for involvement may result in failure for a variety of reasons, but to the extent that the factors inhibiting successful initiation or continuation are manageable, than the constraint negotiation process may be reinitiated. But it may well be that constraints in one direction may have the happy consequence of leading a person in another (Kleiber, McGuire et al., 2008). In any case, it is wise to remind prospective retirees of Weiss' conclusion to his book on experiencing retirement: "Even in retirement especially in retirement - there is always something to do" (2008: 192).

That said, it is also important to remind retirees of one of the central virtues of leisure, and that is the freedom to relax, to not "do" something, to take a posture of openness to what the world offers without necessarily acting on it, to just "be". To decide simply to find peace in one's existence may be one of the most important commitments one could make.

\section{Conclusion}

If this review of the realities of retirement preparation in the United States and Spain tells us anything, it is that in both countries there is a significant need for more of it, and that the incorporation of leisure education into such programs is also warranted. The differences between the two countries in when and how retirement occurs will no 
lación influyen, sin duda, en la naturaleza y el alcance de la educación para el ocio en un programa de preparación para la jubilación. Y, al examinar las evidencias existentes sobre la jubilación, podemos reconocer que una amplia gama de situaciones dentro de los dos países en lo tocante a la preparación y adaptación a la jubilación dictarían un enfoque complejo, tendente a la individualización de esta educación. Pero, quizás, podamos estar de acuerdo en que, en cualquier caso, es necesario reconsiderar de algún modo las actitudes hacia el trabajo y el ocio a todo lo largo del proceso. Una jubilación feliz puede depender de ello, independientemente, hasta cierto punto, de las circunstancias.

\section{Referencias bibliográficas / References}

Adams, G. A. \& Beehr, T.A. (eds.) (2003): Retirement: Reasons, processes and results. New York: Springer.

Adams, K. B. (2004). Changing investment in activities and interests in elders' lives: Theory and measurement. International Journal of Aging and Human Development, 58, 87-108.

Adams, K. B., Leibbrandt, S. \& Moon, H. (2011). A critical review of the literature on social and leisure activity and wellbeing in later life. Ageing \& Society, 31, 683-712

Albrechtsen, S. J. (2001). Technology and lifestyles: Challenges for leisure education in the new millennium. World Leisure, 43, 11-19.

Antonovsky, A., \& Sagy, S. (1990). Confronting developmental tasks in the retirement transition. The Gerontologist, 30, 362-368.

Atchley, R.C. (1989). A continuity theory of normal aging. The Gerontologist, 29(2), 183-190.

Baltes, P. B., \& Baltes, M. M. (1998). Savior vivre in old age: How to master the shifting balance between gains and losses. National Forum, 78(2), $13^{-18 .}$

Barrera, E., Malagón, J.L. \& Sarasola, J.L. (2008). El papel de la empresa en la preparación a la jubilación. Revista del Ministerio de Trabajo e Inmigración, 76, 15-38. doubt influence the nature and reach of leisure education in a retirement preparation program. And we can recognize from reviewing the existing evidence on retirement that the great range of situations within the separate countries with respect to retirement preparation and adjustment would dictate a complex approach to individualizing this education. But perhaps we can agree that attitudes toward work and leisure must be reconsidered in some way in the process in any case. A happy retirement may depend on it, whatever the circumstances.

Bryant, F., \& Veroff, J. (2007). Savoring: A new model of positive experience. Mahwah, NJ: Erlbaum.

Bullock, C., Mahon M., \& Killingsworth, C (2011). Introduction to recreation services for people with disabilities: A person centered approach ${ }_{2} \mathrm{rd}$ ed.). Champaign, IL: Sagamore Publishers.

Caasanti, T.M. (1996). Gender and life satisfaction in retirement: An assessment of the male model. Journal of Gerontology: Psychological Science and Social Science, 51, 18-29.

Chiriboga, D. A., \& Pierce, R. C. (1993). Changing contexts of activity. In J. R. Kelly (Ed.), Activityand aging: Staying involved in later life (pp. 42-59). Newbury Park, CA: Sage Publications.

Csikszentmihlay, M. (1990). Flow. New York: Basic Books.

Csikszentmihalyi, M., \& LeFevre, J. (1989). Optimal experience in work and leisure. Journal of Personality and Social Psychology, 56, 815-822.

Cuenca Cabeza, M. (1996). Ocio autotélico y educación. Revista de Ciencias de la Educación, 165, 13-35.

Cuenca Cabeza, M. (2000). Ocio humanista. Dimensiones y manifestaciones actuales del ocio. Bilbao, Spain: Universidad de Deusto. 
Cuenca Cabeza, M. (2004). Pedagogía del ocio: Modelos y propuestas. Bilbao, Spain: Universidad de Deusto.

Dattilo, J. (2008). Leisure education program planning: A systematic approach. State College, PA: Venture Press.

deGrazia, S. (1962). Of time, work, and leisure. New York, NY: Anchor Books, Doubleday.

Dupuis, S.L. \& Smale, B.J. (1995). An examination of relationships between psychological wellbeing and depression and leisure activity participation among older adults. Society and Leisure, 18, 67-92.

Ekerdt, D. J. (1986). The busy ethic: Moral continuity between work and retirement. The Gerontologist, 26, 239-244.

Erikson, E. (1959). Identity and the life cycle. New York: Norton.

Freedman, M. (1999). Prime time: How Baby Boomers will revolutionize retirement and transform America. Cambridge MA: Perseus.

Fredrickson, B. (2001). The role of positive emotions in positive psychology: The broaden and build theory of positive emotions. American Psychologist, 56, 218-226.

Fredrickson, B. (2003). The value of positive emotions. American Scientist, 91, 330-335.

Gee, S. \& Baillie, J. (1999). Happily ever after? An exploration of retirement expectations. Educational Gerontology, 25, 109-128.

Glamser, F.D. (1991). The impact of preretirement programs on the retirement experience. Journal of Gerontology, 36, 244-250

Glamser, F.D. \& DeJong, G.F. (1975). The efficacy of preretirement preparation programs for industrial workers. Journal of Gerontology, 30, 595600.

Gordon, C., Gaitz, C. M. \& Scott, J. (1976). Leisure and lives: Personal expressivity across the life span. In R. Binstock and E. Shanas (Eds.), Handbook of aging and the social sciences (pp. 310-341). New York, NY: Van Nostrand Reinhold Company.

Hayslip, B., Beyerlein, M. \&Nichols, J. (1997). Assessing Anxiety About Retirement: The Case of Academicians. The International Journal of Aging and Human Development, 44, 15-36.
Hemingway, J. L. (1988). Leisure and civility: Reflections of a Greek ideal. Leisure Sciences, 10, 179-191.

IMSERSO (1999). Boletín sobre el envejecimiento: perfiles y tendencias. Madrid: IMSERSO.

IMSERSO (2000). Las personas mayores en España. Informe 2000. Datos estadísticos estatales y por comunidades autónomas. 2 vols. Madrid: IMSERSO.

Jackson, E. L., Crawford, D. W., \& Godbey, G. (1992). Negotiation of leisure constraints. Leisure Sciences, 15, 1-12.

Janke, M., Son, J. S., \& Payne, L. L. (2009). Self-regulation and adaptation of leisure activities among adults with arthritis. Activities, Adaptation, \& Ag ing, 33, 65-80.

Katz, S. (2000). Busy bodies: Activity, aging, and the management of everyday life. Journal of $A g-$ ing Studies, 14, 135 - 15.

Katz, S. (2001). Growing older without aging? Positive aging, anti-ageism, and anti-aging. Generations, 25(4), 27-32.

Kim, J.E. \& Moen, P. (2002). Retirement transitions, gender, and psychological well-being: a lifecourse, ecological model. Gerontology B: Psychological Science and Social Science, 57, 21222.

Kimmel, D., Price, P. \&Walker, J (1978). Retirement choice and retirement satisfaction, Journal of Gerontology, 33, 575-585

Kleiber, D. (1999). Leisure experience and human development. NYC: Basic Books.

Kleiber, D. (2012). Taking leisure seriously: New and older considerations about leisure education. World Leisure (accepted).

Kleiber, D.A., Hutchinson, S.L., \& Williams, R. (2002). Leisure as a resource in transcending negative life events: Self-protection, self-restoration and personal transformation. Leisure Sciences, 24, $219-235$.

Kleiber, D. A., McGuire, F., Aybar-Damali, B., \& Norman, W. (2008). Having more by doing less: The paradox of leisure constraints in later life. Journal of Leisure Research, 40, 343-359.

Mannell, R. C. (1984). Personality in leisure theory: The self-as-entertainment construct. Loisir et Société/Society and Leisure, 7, 229-242.

[ 174 ] Douglas A. Kleiber, Fernando Bayón Martín y Jaime Cuenca Amigo SIPS - PEDAGOGIA SOCIAL. REVISTA INTERUNIVERSITARIA [1139-1723 (2012) 20, 137-176] • TERCERA EPOCA 
Mannell, R. C. (1993). High investment activity and life satisfaction among older adults: Committed, serious leisure and flow activities. In J. R. Kelly (Ed.), Activity and aging (pp. 125-145). Newbury Park, CA: Sage Publications.

Maynard, S. S., \& Kleiber, D. A. (2005). Using leisure services to build social capital in later life: Classical traditions, contemporary realities, and emerging possibilities. Journal of

Leisure Research, 37(4), 475-493.

McCrae, R. R., \& Costa, P. T. (1999). A five-factor theory of personality. In L. A. Pervin \& O. P. John (eds.), Handbook of personality: Theory and research. (2nd ed., pp. 139-153). New York, NY: Academic Press.

Menec, V.H. (2003). The relation between everyday activities and successful aging: A 6-Year longitudinal study. Journals of Gerontology, 58B, 74-82.

Mishra, S. (1992). Leisure activities and life satisfaction in old age: a case study of retired government employees living in urban areas. Activities, Adaptation and Aging, 16(4), 7-26.

Monteagudo- Sánchez, M.J. (2008). Reconstruyendo la experiencia de ocio: características, condiciones de posibilidad y amenazas en la sociedad de consumo. In M.J. Monteagudo- Sánchez (ed.) La experiencia de ocio: Una mirada científica desde los estudios de ocio. Bilbao, Spain: Universidad de Deusto.

Moragas, R., Rivas, P., Cristofol, J., Rodríguez, N. \& Sánchez, C. (2007) Prevención de la dependencia. Preparación para la jubilación (II). Barcelona: Universidad de Barcelona.

MTAS (MINISTERIO DE TRABAJO Y ASUNTOS SOCIALES (1999). Plan de acción para las personas mayores 2000-2005 (5ํㅡㄴ borrador). Madrid: Ministerio de trabajo y asuntos sociales. Secretaría general de asuntos sociales. Instituto de migraciones y servicios sociales.

Musick, M.A. \& Wilson, J. (2007). Volunteers: A social profile. Bloomington, IN: Indiana University Press.

Nimrod, G. (2008). In support of innovation theory: Innovation in activity patterns and life satisfaction among recently retired individuals. Aging \& Society, 28, 831-846.
Nimrod, G., \& Kleiber, D. A. (2007). Reconsidering change and continuity in later life: Toward an innovation theory of successful aging. International Journal of Aging and Human Development, 65, 1-22.

Pérez, L. (2002). "Formas de convivencia, relaciones personales y la experiencia de envejecer". En Las personas mayores en España. Informe 2002. Madrid: IMSERSO.

Pieper, J. (1952). Leisure: The basis of culture. New York: Pantheon Books.

Reitzes, D.C. \& Mutran, E.J. (2004).The transition to retirement: stages and factors that influence retirement adjustment. International Journal of Aging and Human Development, 59, 63-84

Rowe, J. W. \& Kahn, R. L. (1998). Successful aging. New York: Pantheon Books.

Sáez Carreras, J.; García Molina, J. (2003). Emergencia de las profesiones sociales: de la dimensión discursiva a la dimensión política, ética y práctica. Pedagogía Social. Revista Interuniversitaria, 10, 195ss.

Sáez Narro, N., Aleixandre, M. \& Meléndez, J.C. (1996). Evolución de nivel de necesidades educativas para la preparación de la jubilación en el contexto de la comunidad valenciana. Pad'e, 5(1), 115-128.

Searle, M. S., Mahon, M. J., Iso-Ahola, S., Adam Sdrolias, H., \& van Dyck, J. (1998). Examining the long-term effects of leisure education on a sense of independence and psychological well-being among the elderly. Journal of Leisure Research, 30, 331-340.

Stebbins, R.A. (1992). Amateurs, professionals, and serious leisure. Montreal, Quebec: McGillQueen's University Press.

Stebbins, R. A. (2001). New directions in the theory and research of serious leisure. Lewiston, NY: Edwin Mellen Press.

Sterns, H. \& Gray, J.H. (1995). Work, leisure and retirement. In J.C. Cavanagh \& S.K. Whitbourne. (eds) Gerontology: An interdisciplinary perspective (pp.355-390). New York: Oxford University Press.

Szinovacz, M.E. (2002a). Contexts and pathways: Retirement as institution, process and experience. In G. Adams, \& T. Beehr, (2003). Retirement: Reasons, processes and results (pp. 6-52). New York: Springer. 
Szinovacz, M.E. (2002b). Indicadores sociales. Envejecer en España. Madrid: IMSERSO.

Taylor, M.A. \& Doverspike, D. (2003). Retirement planning and preparation. In G. Adams, \& T. Beehr, (2003). Retirement: Reasons, processes and results. Pp. 53-82. New York: Springer.

\section{DIRECCIÓN DE LOS AUTORES /}

AUTHORS' ADDRESSES: Douglas A. Kleiber. University of Georgia. Department of Counseling and Human Development Services, 353 Ramsey Student Center, University of Georgia, 300 River Road, Athens, GA, USA 30602-6555. Tlf.: (O०1)706-542-4330

Fernando Bayón Martín y Jaime Cuenca Amigo Universidad de Deusto. Instituto de Estudios de Ocio, Avda. Universidades 24, 48007 Bilbao Tlf.: 944139075

Correos electrónicos/e-mail:

dkleiber@uga.edu,

fernandobayon@deusto.es,

jaime.cuenca@deusto.es

Fecha de recepción del artículo /

received date: 10.IV.2012

Fecha de revisión del artículo/

reviewed date: 10.v.2012

Fecha de aceptación final/

accepted date: 12.V.2012
Tornstam, L. (2005). Gerotranscendence: A developmental theory of positive aging. New York City: Springer Publishing.

Weiss, R. S. (2005). The experience of retirement. Ithaca, NY: Cornell University Press.

\section{COMO CITAR ESTE ARTÍCULO/ HOW TO CITE THE ARTICLE:}

Kleiber, D., Bayon Martin, F. y Cuenca Amigo, J. (2012). La educación para el ocio como preparación para la jubilación en Estados Unidos y España. Pedagogia Social. Revista Interuniversitaria, 20, pp. 137-176.

Kleiber, D., Bayon Martin, F. \& Cuenca Amigo, J. (2012). La educación para el ocio como preparación para la jubilación en Estados Unidos y España. Pedagogia Social. Revista Interuniversitaria, 20, pp. 137-176. 